Article

\title{
REE Enrichment during Magmatic-Hydrothermal Processes in Carbonatite-Related REE Deposits: A Case Study of the Weishan REE Deposit, China
}

\author{
Yu-heng Jia ${ }^{1,2}$ and Yan Liu ${ }^{2,3, *}$ \\ 1 Earth Science Institute, Guilin University of Technology, Guilin 541004, China; yuhengjia@glut.edu.cn \\ 2 Key Laboratory of Deep-Earth Dynamics of Ministry of Natural Resources, Institute of Geology, \\ Chinese Academy of Geological Science, Beijing 100037, China \\ 3 Southern Marine Science and Engineering Guangdong Laboratory (Guangzhou), Guangzhou 511458, China \\ * Correspondence: ly@cags.ac.cn
}

Received: 22 August 2019; Accepted: 20 December 2019; Published: 27 December 2019

\begin{abstract}
The Weishan carbonatite-related rare earth element (REE) deposit in China contains both high- and low-grade REE mineralization and is an informative case study for the investigation of magmatic-hydrothermal REE enrichment processes in such deposits. The main REE-bearing mineral is bastnäsite, with lesser parisite and monazite. REE mineralization occurred at a late stage of hydrothermal evolution and was followed by a sulfide stage. Barite, calcite, and strontianite appear homogeneous in back-scattered electron images and have high REE contents of 103-217, 146-13,120, and 194-16,412 ppm in their mineral lattices, respectively. Two enrichment processes were necessary for the formation of the Weishan deposit: Production of mineralized carbonatite and subsequent enrichment by magmatic-hydrothermal processes. The geological setting and petrographic characteristics of the Weishan deposit indicate that two main factors facilitated REE enrichment: (1) fractures that facilitated circulation of ore-forming fluids and provided space for REE precipitation and (2) high ore fluorite and barite contents resulting in high $\mathrm{F}^{-}$and $\mathrm{SO}_{4}{ }^{2-}$ concentrations in the ore-forming fluids that promoted REE transport and deposition.
\end{abstract}

Keywords: mineralogical characteristics; disseminated REE ores; carbonatite-syenite complex; Weishan deposit; Shandong Province

\section{Introduction}

More than 500 carbonatite intrusions are known worldwide [1], but there are few known large or giant carbonatite-related rare earth element (REE) deposits (CARDs). Most currently mined large or giant deposits are in China [2] but there are other examples: Mountain Pass, USA ( $\mathrm{REO} \geq 29 \mathrm{Mt} ; \mathrm{RE}_{2} \mathrm{O}_{3} \sim 8.9 \%$; $\mathrm{REO}=$ total rare earth oxides; $\mathrm{Mt}=$ megatonne) [3]; Kvanefjeld, Greenland (REO $\geq 6.55 \mathrm{Mt} ; \mathrm{RE}_{2} \mathrm{O}_{3}$ $\sim 1.06 \%$ ); Main in Thailand ( $\mathrm{REO} \geq 4.25 \mathrm{Mt}: \mathrm{RE}_{2} \mathrm{O}_{3} \sim 3.21 \%$ ); Khibina in Russia ( $\mathrm{REO} \geq 10 \mathrm{Mt} ; \mathrm{RE}_{2} \mathrm{O}_{3}$ $\sim 0.85 \%$ ); Montviel carbonatite REE deposits in Canada [4]. Here the term REE is used to include the 14 naturally occurring lanthanides and Y, but not Sc. Giant deposits with reserves in excess of $1 \mathrm{Mt}$ REO are exceptionally rare. REEs have become vital in manufacturing numerous high-technology products. Between 2011 and 2017, China produced $~ 84 \%$ of the world supply of REEs, with the USA only producing REEs from 2012-2015. The USA production came entirely from the Mountain Pass mine (California), which provided $\sim 4 \%$ of the world's REE supply [5]. A wide variety of REE deposits occurs in China [6,7], including CARDs formed from REE-rich fluids exsolved from carbonatitic melts [8], which is the most common type of REE mineralization in China, accounting for $\sim 65 \%$ of total reserves, including the Bayan Obo deposit [9,10], Mianning-Dechang REE belt [11-13], and Weishan deposit of Shandong Province [14,15]. All the deposits are located along cratonic margins and have several 
similar features (Table 1). Other CARDs include Mountain Pass [3], Oka [4], Canada, and Mt. Weld in Australia [16]; Araxa and Catalao I in Brazil [17,18]; Tomtor in Russia [19]; Mrima Hill in Kenya [20]; Mabouni in Gabon; and several other carbonatitic laterites in the Amazon region of Brazil [21].

These deposits all occur along cratonic margins and have similar geological settings, ore sources, and mineral paragenetic sequences [12]. The known CARDs in China have been well studied, with their petrogenetic processes being well constrained. Carbonatites may be considered as either mineralized or barren in terms of their REE contents. However, some carbonatites do not form REE deposits. For example, a mineralized carbonatitic melt can have low REE contents in response to limited fractional crystallization [22,23]. Moreover, carbonatites rarely produce high-grade REE ores, as in the Qieganbulake deposit of Xinjiang [24] and Miaoya deposit of Hubei [25,26]. Therefore, a second magmatic-hydrothermal process appears to be vital for the formation of high-grade REE deposits.

Several studies have shown that magmatic processes can be responsible for high-grade REE mineralization, especially that hosted in pegmatitic granite $[27,28]$. However, recent studies of carbonatite-hosted REE deposits found that a second magmatic-hydrothermal process was required to form high-grade REE deposits [13,29-33]. Recent exploration of the Weishan deposit has identified large volumes of various types of ore with different grades. The Weishan alkaline intrusive complex lies on the southeastern margin of the North China Craton (NCC). The REE deposit is $18 \mathrm{~km}$ southeast of Zaozhuang City in Weishan County, Shandong Province, within the Luxi tectonic block on the southeastern margin of the NCC (Figure 1). It covers $\sim 4 \mathrm{~km}^{2}$ and $>24$ carbonatite-related ore veins have been found, which are each up to $500 \mathrm{~m}$ long (Figure 2). The REO grade of these ore veins is $1.76-14.62 \%$ (average $=5.67 \%$ ) [15]. These well-exposed ores are ideal for the study of the formation of this deposit, as they comprise both REE and gangue minerals, and display a clear, traceable sequence of formation. In this study, petrological and analytical methods, such as X-ray diffraction (XRD), electron microprobe (EPMA), and laser ablation inductively coupled plasma mass spectrometry (LA-ICP-MS) have been applied to elucidate the mechanisms of REE transport and mineralization. The main objectives of the study were to characterize REE mineralization in the Weishan deposit, and to identify the factors that facilitated the magmatic-hydrothermal enrichment of REEs. 
Table 1. Summary of the geological characteristics of the Weishan and Mianning-Dechang REE deposits.

\begin{tabular}{|c|c|c|c|c|c|c|c|c|}
\hline Deposit & Structure & Wall-Rock & Mineral Assemblage in Ores & Alteration & $\begin{array}{l}\text { REO Tonnage } \\
\text { and Grade }\end{array}$ & Orebody Form & Ore Type & Reference \\
\hline Weishan & $\begin{array}{l}\text { Dongpinghu- } \\
\text { Weishan fault }\end{array}$ & Gneiss & $\begin{array}{l}\text { Quartz, calcite, Sr-barite, } \mathrm{Sr} / \mathrm{Pb} \\
\text { barite, Pb-barite, bastnäsite, } \\
\text { parisite, anatas }\end{array}$ & $\begin{array}{l}\text { Albitization, } \\
\text { K-feldspathization }\end{array}$ & $\begin{array}{l}0.193 \mathrm{Mt}, \\
4.61 \text { wt. \% }\end{array}$ & Lenticular, vein & Disseminated, banded & Wang et al. (2016) [15] \\
\hline Maoniuping & $\begin{array}{l}\text { Haha strike-slip } \\
\text { fault }\end{array}$ & $\begin{array}{l}\text { Granite, } \\
\text { basalt, } \\
\text { rhyolite, } \\
\text { syenite, } \\
\text { carbonatite }\end{array}$ & $\begin{array}{l}\text { Microcline, quartz, biotite, } \\
\text { aegirine, aegirine-augite, } \\
\text { arfvedsonite, chevkinite, } \\
\text { calcite, fluorite, barite, } \\
\text { celestine, bastnäsite, fluorite, } \\
\text { barite, quartz, bastnäsite, } \\
\text { Fe-Mn oxides, calcite }\end{array}$ & Biotitization & $\begin{array}{c}3.17 \mathrm{Mt} \\
2.95 \text { wt. \% }\end{array}$ & $\begin{array}{l}\text { Semi-layered, } \\
\text { banded, } \\
\text { irregularlens, } \\
\text { pocket }\end{array}$ & $\begin{array}{l}\text { Breccia, stringer } \\
\text { (stockwork), weathered }\end{array}$ & $\begin{array}{l}\text { Yuan et al. (1995) [34]; } \\
\text { Liu and Hou (2017) [13]; } \\
\text { Yang et al. (2000) [35] }\end{array}$ \\
\hline Dalucao & $\begin{array}{l}\text { Dalucao } \\
\text { strike-slip fault }\end{array}$ & $\begin{array}{l}\text { Quartz diorite, } \\
\text { syenite, } \\
\text { carbonatite }\end{array}$ & $\begin{array}{l}\text { Microcline, quartz, biotite, } \\
\text { aegirine, aegirine-augite, } \\
\text { calcite, fluorite, barite, } \\
\text { celestine, bastnäsite, fluorite, } \\
\text { barite, quartz, bastnäsite }\end{array}$ & $\begin{array}{l}\text { biotitization, } \\
\text { fenitization }\end{array}$ & $\begin{array}{c}0.082 \mathrm{Mt} \\
5.21 \mathrm{wt} . \%\end{array}$ & $\begin{array}{l}\text { Lenticular, pipe-like } \\
\text { with minor veining, } \\
\text { ponded, brecciated }\end{array}$ & $\begin{array}{l}\text { Brecciaed, barite, fluorite, } \\
\text { bastnäsite, celestine, } \\
\text { fluorite, bastnäsite, stringer, } \\
\text { massive, block-like } \\
\text { disseminated, weathered }\end{array}$ & $\begin{array}{c}\text { Shi and Li (1996) [36]; } \\
\text { Yang et al. (1998) [37]; } \\
\text { Liu et al. (2015b, c) } \\
{[38,39]}\end{array}$ \\
\hline Lizhuang & $\begin{array}{l}\text { Intersections of } \\
\text { NE- and } \\
\text { NW-strikin } \\
\text { strike-slip faults }\end{array}$ & $\begin{array}{l}\text { Granite, syenite, } \\
\text { carbonatite }\end{array}$ & $\begin{array}{l}\text { Fluorite, barite, quartz, } \\
\text { bastnäsite }\end{array}$ & $\begin{array}{l}\text { Biotitization, } \\
\text { fenitization }\end{array}$ & $\begin{array}{c}0.0058 \mathrm{Mt} \\
1.47-1.63 \mathrm{wt} . \%\end{array}$ & $\begin{array}{l}\text { Semi-layered, } \\
\text { banded, } \\
\text { irregular lens, } \\
\text { brecciated }\end{array}$ & $\begin{array}{c}\text { Brown disseminated, } \\
\text { yellow banded, stockwork, } \\
\text { black powder-like, } \\
\text { brecciated, weathered }\end{array}$ & Hou et al. (2008) [40] \\
\hline Muluozhai & $\begin{array}{l}\text { Yalongjiang } \\
\text { strike-slip fault }\end{array}$ & $\begin{array}{l}\text { Granite, } \\
\text { syenite, } \\
\text { carbonatite }\end{array}$ & $\begin{array}{l}\text { Fluorite, barite, quartz, } \\
\text { gypsum, bastnäsite }\end{array}$ & Botitization & $\begin{array}{c}0.1 \mathrm{Mt} \\
3.66 \text { wt. \% }\end{array}$ & $\begin{array}{l}\text { Semi-layered, } \\
\text { banded, } \\
\text { irregular lens, } \\
\quad \text { veinlet }\end{array}$ & $\begin{array}{c}\text { Massive, } \\
\text { impregnated, banded }\end{array}$ & Liu and Hou (2017) [13] \\
\hline
\end{tabular}




\section{Geological Setting}

The Weishan REE deposit lies in the southern part of the uplifted region of Shandong Province, which is $\sim 120 \mathrm{~km}$ west of the Yishu Fault (Figure 1) that is the main structure in the deposit and occurs in the central part of the Tanlu Fault. A NW-SE- and E-W-striking fault system affected by the Yishu Fault also occurs in the deposit [41,42]. These structures controlled the distribution of sedimentary and igneous rocks. Mesozoic compressional tectonism was followed by development of the Luxi Uplift, coeval with the change from dominantly compressional to Mesozoic extensional tectonism in eastern North China [43]. Four sets of small faults are controlled by local structures: NW-SE-, E-W-, and NE-SW-trending compressional and scissor faults, N-S-trending extensional faults, and NW-SEand NE-SW-trending faults are the main ore-bearing structures. The shapes, occurrences, and sizes of ore veins are controlled by these faults [15,44].
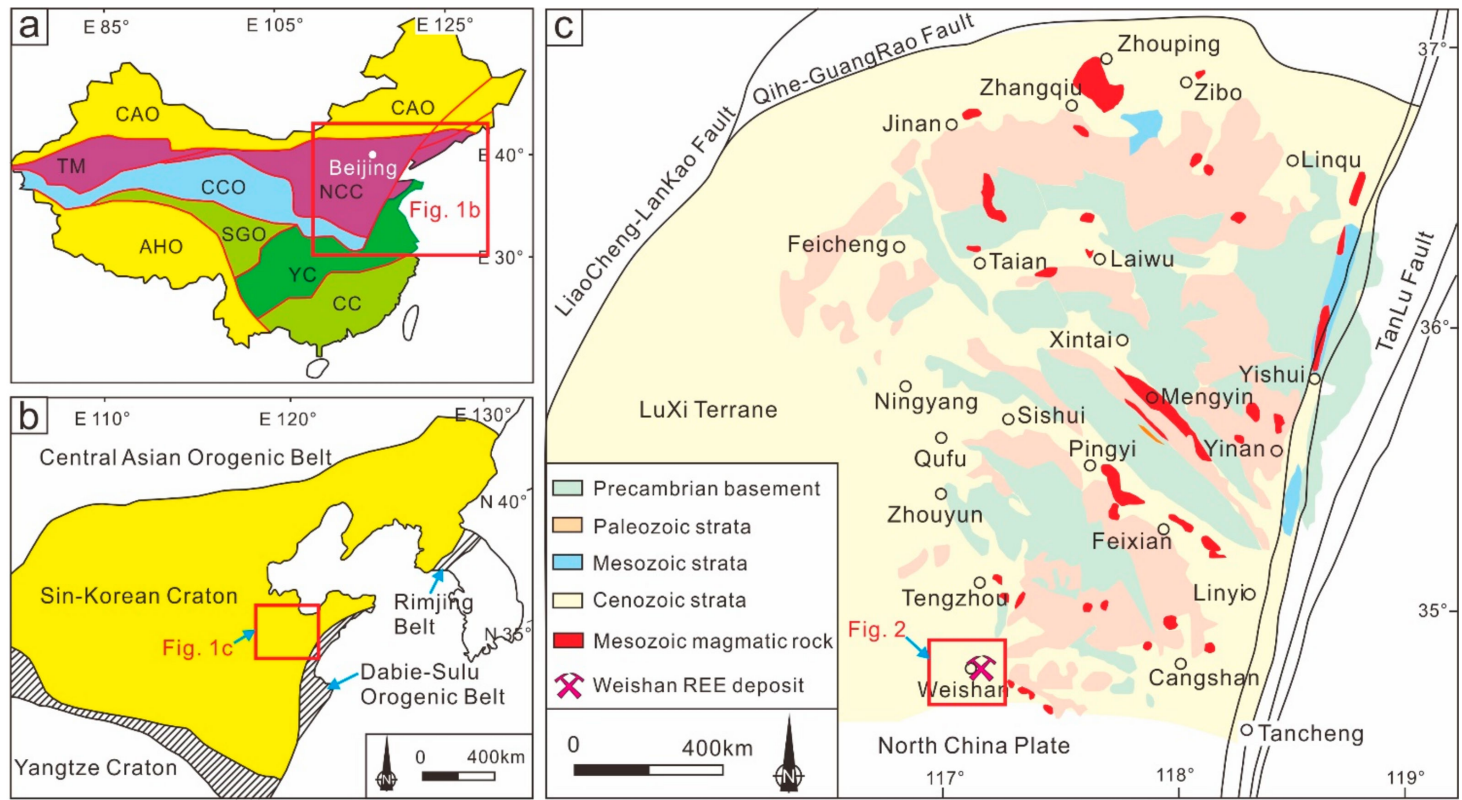

Figure 1. (a) Simplified geological map showing the major tectonic units in eastern China and the location of the Luxi Block (modified from references $[14,45,46]$ ). (b) Map showing the distribution of Triassic alkaline igneous rocks on the northern margin of the Sino-Korean craton (location in inset map, which shows the main tectonic units of China; modified from reference [47]). (c) Geological map of the Luxi Block (modified from references [14,48]). 


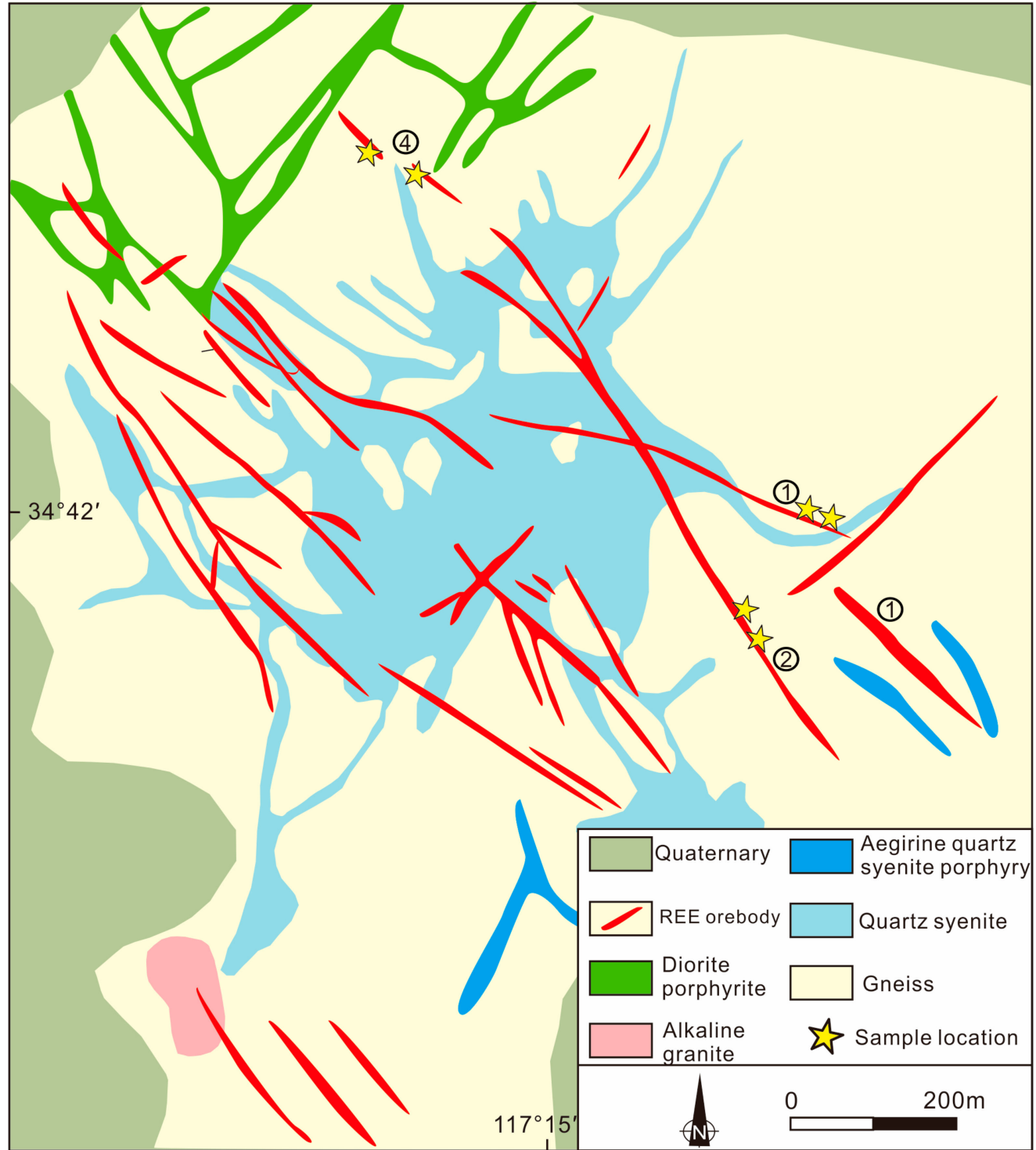

Figure 2. Geological sketch map of the Weishan rare earth element (REE) deposit in Shandong Province (modified from reference [49]).

Host rocks of the Weishan REE deposit are mainly biotite-plagioclase gneiss of the Shancaoyu Formation of the Archean Taishan Group [44]. Quaternary strata are also well exposed. Igneous rocks in the mining area comprise mainly Early Cretaceous quartz syenite, aegirine-augite quartz syenite porphyry, and alkaline granite, as well as dikes of dioritic porphyry, lamprophyre, and aplite (Figure 2). Peak magmatism in western Shandong Province occurred during the Mesozoic, when a range of mantle-derived igneous rocks was formed, including intrusive rocks, K-rich volcanic rocks, and lamprophyres. The Yanshanian subalkaline complex, which is also in this district, comprises dioritic porphyry, syenite, syenitic porphyry, diabase, and lamprophyre, which commonly occur as batholiths, stocks, and dikes [14,50].

Lan [14] and Liang [50] determined formation ages of syenite and related REE deposits in Weishan as follows: zircon LA-ICP-MS U-Pb ages of ore-bearing quartz syenite and aegirine-augite syenite are $122.4 \pm 2.0$ and $130.1 \pm 1.4 \mathrm{Ma}$, respectively; $253.6 \pm 6.1 \mathrm{Ma}$ inherited zircons were assimilated during magma ascent and/or emplacement. Based on a Rb-Sr isochron age of 119.5 $\pm 1.7 \mathrm{Ma}$ for muscovite in REE ore veins [16] and the timing of syenite formation, Liang [50] concluded that the Weishan alkaline magma was derived from enriched asthenospheric mantle in an extensional setting 
after the transformation from a compressional to an extensional tectonic regime in the NCC during the Mesozoic.

Geochemical analyses indicate that syenite of the Weishan alkaline igneous complex is of the metaluminous-alkaline series. The syenites have high total REE ( $\mathrm{REE}$ ) contents of 633-4418 ppm, distinct fractionation of heavy and light REE (HREE and LREE), depletion in HREE, $\mathrm{Nb}, \mathrm{Ta}$, and $\mathrm{Zr}$, enrichment in LREE, $\mathrm{Rb}, \mathrm{Ba}$, and $\mathrm{Sr}$, and both positive and negative Eu anomalies $\left(\mathrm{Eu} / \mathrm{Eu}^{*}=0.90-1.05\right)$, consistent with characteristics of enriched asthenospheric mantle-derived melts [50].

\section{Ore Types and Samples}

\subsection{Ore Descriptions}

Groups of ore veins with regular shapes in the Weishan deposit occur in syenite, gneiss, and alkaline granite, and aegrine-augite-quartz syenite porphyry occurs along fissures in these rocks. The main REE mineral is bastnäsite and the common gangue minerals are fluorite, barite, quartz, and calcite. Single ore veins are regular, thick (0.1-9.2 m), and continuous (30-540 m) [50], clearly cutting wall-rock syenite. Ore veins are subdivided into fluorite, quartz-barite, and quartz-calcite types (Figure 3a,b,e,f). Based on the types of minerals and grain sizes, the veins also could be divided into four sub-types: (1) REE-bearing quartz + fluorite + barite, celestite + calcite + pyrite, galena, and sphalerite veins, with groups of REE-bearing carbonate veinlets (1-2 mm wide) making up networks (Figure 3a,b); (2) REE-bearing veins in aegirine granite porphyry; (3) REE-bearing aegirine-augite veins; and (4) britholite veins. REE-bearing quartz + fluorite + sulfate + carbonate + sulfide veins are predominant. Veinlets occur around ore veins, intersecting one another (Figure 3c,d), and disseminated ores occur in veinlets along fractures (Figure 4). Disseminated REE ores and micro-veinlets in Neoarchean gneiss and Early Cretaceous intrusive rocks, including aegirine-augite syenite [14], also occur. Based on the mineral assemblages of the REE ores and micro-veinlets and their formation temperatures $\left(200-550{ }^{\circ} \mathrm{C}\right)$ [14], REE-bearing aegirine veins in granitic porphyry and REE-bearing aegirine-augite veins formed during the hydrothermal stage and earlier than REE-bearing quartz + fluorite + sulfate + carbonate + sulfide veins. Britholite veins formed during the transition from magmatic to hydrothermal fluid stages $[14,49,51]$.

Disseminated ore samples from networks of REE-bearing carbonate veinlets in the Weishan REE deposit are mainly massive and comprise calcite, barite, quartz, and REE minerals, such as bastnäsite, parisite, monazite, and ancylite. Several further typical ore samples from the ore veins were also selected for comparison (Figure 3). The characteristics of all the samples in this study are listed in Table 2. 
Table 2. Key features of samples from the Weishan REE deposit.

\begin{tabular}{|c|c|c|c|c|c|c|c|}
\hline Samples No. & Ore Type & Orebody No. & Thickness (m) & Length (m) & Essential Mineral & Type/Subtype of Vein & Characteristics \\
\hline SDW16-1 & $\begin{array}{l}\text { Disseminated } \\
\text { ore }\end{array}$ & 1 & $0.22-10.14$ & 258 & $\begin{array}{l}\text { green mineral, } \\
\text { quartz, dark } \\
\text { mineral, a small } \\
\text { amount of pyrite. }\end{array}$ & $\begin{array}{l}\text { (1) REE-bearing quartz + } \\
\text { fluorite + barite, celestite + } \\
\text { calcite + pyrite, galena, } \\
\text { and sphalerite veins, with } \\
\text { groups of REE-bearing } \\
\text { carbonate veinlets }(1-2 \mathrm{~mm} \\
\text { wide) making up networks }\end{array}$ & $\begin{array}{l}\text { The sample is massive, mainly composed of calcite, which drops } \\
\text { violently when hydrochloric acid is applied on it, and the xenomorphic, } \\
\text { granular, grey, oily luster quartz scattered within it, 3-5 mm in } \\
\text { diameter; a little melanic mineral distributed in the form of ribbon-like, } \\
\text { with the width of about 1-3 mm and good continuity. The other side of } \\
\text { the hand specimen is mainly pink calcite, containing some quartz and } \\
\text { dark mineral (5\% to } 8 \% \text { ). A small mineral of yellowish brown; sparsely } \\
\text { disseminated in green minerals and pale pink calcite. }\end{array}$ \\
\hline SDW16-2 & $\begin{array}{l}\text { Disseminated } \\
\text { ore }\end{array}$ & 1 & $0.22-10.14$ & 258 & $\begin{array}{l}\text { calcite, quartz, } \\
\text { gypsum group, } \\
\text { galena, pyrite }\end{array}$ & $\begin{array}{l}\text { (1) REE-bearing quartz + } \\
\text { fluorite + barite, celestite + } \\
\text { calcite + pyrite, galena, } \\
\text { and sphalerite veins, with } \\
\text { groups of REE-bearing } \\
\text { carbonate veinlets ( } 1-2 \mathrm{~mm} \\
\text { wide) making up networks }\end{array}$ & $\begin{array}{l}\text { The whole rock is shallow red flesh, massive, mainly composed of light } \\
\text { red calcite, light yellow barite, quartz and a small amount of bastnäsite } \\
\text { composition. The quartz is randomly distributed, xenomorphic, } \\
\text { granular, gray, and transparent, oily luster, with a content of about } 5 \% \text {. } \\
\text { The white mineral is calcite, account for 3\%. The crystalline pyrite is } \\
\text { well developed, the particle size is } 1-2 \mathrm{~mm} \text {, and the content is about } \\
2 \% \text {. The sallow colored bastnäsite are discontinuous and banded } \\
\text { distributed in light yellow barite and red calcite. A small amount of } \\
\text { galena having metallic luster with a content } 1 \% \text { to } 3 \% \text {. }\end{array}$ \\
\hline SDW16-3 & $\begin{array}{l}\text { Disseminated } \\
\text { ore }\end{array}$ & 1 & $0.22-10.14$ & 258 & $\begin{array}{l}\text { calcite, quartz, } \\
\text { barite, galena dark } \\
\text { mineral }\end{array}$ & $\begin{array}{l}\text { (1) REE-bearing quartz + } \\
\text { fluorite + barite, celestite + } \\
\text { calcite + pyrite, galena, } \\
\text { and sphalerite veins, with } \\
\text { groups of REE-bearing } \\
\text { carbonate veinlets (1-2 mm } \\
\text { wide) making up networks }\end{array}$ & $\begin{array}{l}\text { The whole is massive, red, mineral mainly conclude red calcite, with a } \\
\text { small amount of white calcite, yellow barite and quartz. Quartz is } \\
\text { smoke gray and granular, local particles larger, up to } 3-6 \mathrm{~mm} \text {, account } \\
\text { for } 3 \% \text { to } 8 \% \text {. Galena with a metallic luster on its surface, with content } \\
\text { of } 2 \% \text { to } 3 \% \text {, approximately banded. Containing a small amount of } \\
\text { yellowish brown bastnäsite disseminated in other minerals. }\end{array}$ \\
\hline SDW16-4 & $\begin{array}{l}\text { Disseminated } \\
\text { ore }\end{array}$ & 1 & $0.22-10.14$ & 258 & $\begin{array}{c}\text { calcite, barite, } \\
\text { quartz, dark } \\
\text { mineral, pyrite }\end{array}$ & $\begin{array}{l}\text { (1) REE-bearing quartz + } \\
\text { fluorite + barite, celestite + } \\
\text { calcite + pyrite, galena, } \\
\text { and sphalerite veins, with } \\
\text { groups of REE-bearing } \\
\text { carbonate veinlets ( } 1-2 \mathrm{~mm} \\
\text { wide) making up networks }\end{array}$ & $\begin{array}{l}\text { The whole rock is red and massive with dark mineral veins. } \\
\text { The mineral is mainly composed of flesh red calcite }(60 \%) \text { and dark } \\
\text { mineral (vein) }(40 \%) \text {. Red calcite contains a small amount of yellow } \\
\text { barite. The dark minerals are banded and with good continuity, with } \\
\text { disseminated pyrite distributed in the dark mineral veins, accounting } \\
\text { for about } 5 \% \text {; and a small amount of quartz distributed sporadically. } \\
\text { The red calcite is continuous and banded in the dark mineral veins. } \\
\text { Dark mineral veins are partly in contact with red calcite without } \\
\text { obvious alteration. }\end{array}$ \\
\hline SDW16-5 & $\begin{array}{l}\text { Disseminated } \\
\text { ore }\end{array}$ & 1 & $0.22-10.14$ & 258 & $\begin{array}{l}\text { calcite, barite, } \\
\text { bastnäsite, quartz, } \\
\text { pyrite, galena, } \\
\text { muscovite }\end{array}$ & $\begin{array}{l}\text { (1) REE-bearing quartz + } \\
\text { fluorite + barite, celestite + } \\
\text { calcite + pyrite, galena, } \\
\text { and sphalerite veins, with } \\
\text { groups of REE-bearing } \\
\text { carbonate veinlets (1-2 mm } \\
\text { wide) making up networks }\end{array}$ & $\begin{array}{l}\text { The whole is light pale, bearing some white or red calcite and dark } \\
\text { mineral, forming clear taxitic structure. The main mineral is light pale } \\
\text { barite. Yellow brown bastnäsite are flaky and unevenly distributed in } \\
\text { pale barite, with different sizes. Steel gray galena aggregates, content } \\
\text { of } 5 \% \text { to } 8 \% \text {; a little red calcite distributed in pale barite; in addition, } \\
\text { the visible part of anhedral granular grey quartz, diameter } 2-4 \mathrm{~mm} \text {, } \\
\text { inclusion distribution in barite, content in } 5 \% \text { to } 8 \% \text {. A small amount of } \\
\text { pyrite, granular, particle size } 1-2 \mathrm{~mm}, 1 \% \text { to } 2 \% \text {, a very small amount } \\
\text { of Muscovite distribution in barite, particle size }<3 \mathrm{~mm} \text {. }\end{array}$ \\
\hline
\end{tabular}


Table 2. Cont.

\begin{tabular}{|c|c|c|c|c|c|c|c|}
\hline Samples No. & Ore Type & Orebody No. & Thickness (m) & Length $(\mathrm{m})$ & Essential Mineral & Type/Subtype of Vein & Characteristics \\
\hline SDW16-6 & $\begin{array}{l}\text { Disseminated } \\
\text { ore }\end{array}$ & 4 & $0.30-5.75$ & 258 & $\begin{array}{l}\text { calcite, bastnäsite, } \\
\text { quartz, pyrite }\end{array}$ & $\begin{array}{l}\text { (1) REE-bearing quartz + } \\
\text { fluorite + barite, celestite + } \\
\text { calcite + pyrite, galena, } \\
\text { and sphalerite veins, with } \\
\text { groups of REE-bearing } \\
\text { carbonate veinlets }(1-2 \mathrm{~mm} \\
\text { wide) making up networks }\end{array}$ & $\begin{array}{l}\text { The whole is light red, bearing some white or red calcite, and dark } \\
\text { mineral. The main mineral is calcite. The dark minerals are flaky and } \\
\text { unevenly distributed in calcite, with different sizes. A small amount of } \\
\text { pyrite, granular, particle size } 0.5-1.5 \mathrm{~cm}, 1 \% \text { to } 2 \% \text {. }\end{array}$ \\
\hline SDW17-1 & $\begin{array}{l}\text { Disseminated } \\
\text { ore }\end{array}$ & 4 & $0.30-5.75$ & 258 & $\begin{array}{l}\text { calcite, pyrite, } \\
\text { dark mineral, }\end{array}$ & $\begin{array}{l}\text { (1) REE-bearing quartz + } \\
\text { fluorite + barite, celestite + } \\
\text { calcite + pyrite, galena, } \\
\text { and sphalerite veins, with } \\
\text { groups of REE-bearing } \\
\text { carbonate veinlets }(1-2 \mathrm{~mm} \\
\text { wide) making up networks }\end{array}$ & $\begin{array}{l}\text { The sample is red, mainly composed of light red calcite, green fluorite } \\
\text { and a small amount of dark minerals. Fluorite is disorderly distributed, } \\
\text { accounting for about } 4 \% \text {. A small amount of dark minerals is } \\
\text { developed, accounting for } 1 \% \text { to } 3 \% \text {. }\end{array}$ \\
\hline SDW17-2 & $\begin{array}{l}\text { Disseminated } \\
\text { ore }\end{array}$ & 4 & $0.30-5.75$ & 258 & $\begin{array}{l}\text { calcite, fluorite, } \\
\text { dark mineral, }\end{array}$ & $\begin{array}{l}\text { (1) REE-bearing quartz + } \\
\text { fluorite + barite, celestite + } \\
\text { calcite + pyrite, galena, } \\
\text { and sphalerite veins, with } \\
\text { groups of REE-bearing } \\
\text { carbonate veinlets }(1-2 \mathrm{~mm} \\
\text { wide) making up networks }\end{array}$ & $\begin{array}{l}\text { The whole is composed of pale barite, followed by brown bastnäsite, } \\
\text { interspersed with light green minerals. Massive, granular, } \\
\text { xenomorphic, smoky, gray quartz, oily, lustrous, distributed in other } \\
\text { minerals, } 1-4 \mathrm{~mm} \text { in diameter. A little granular pyrite distributed on } \\
\text { the surface of bastnäsite, accounting for } 1 \% \text {; quartz, bastnäsite and } \\
\text { green mineral with obvious boundary of contact, in addition, there is a } \\
\text { light blue unknow mineral (unlike green mineral), like fluorite } \\
\text { distributed in ores. }\end{array}$ \\
\hline SDW17-3 & $\begin{array}{l}\text { Disseminated } \\
\text { ore }\end{array}$ & 4 & $0.30-5.75$ & 258 & $\begin{array}{c}\text { calcite, quartz, } \\
\text { bastnäsite, dark } \\
\text { mineral }\end{array}$ & $\begin{array}{l}\text { (1) REE-bearing quartz + } \\
\text { fluorite + barite, celestite + } \\
\text { calcite + pyrite, galena, } \\
\text { and sphalerite veins, with } \\
\text { groups of REE-bearing } \\
\text { carbonate veinlets (1-2 mm } \\
\text { wide) making up networks }\end{array}$ & $\begin{array}{l}\text { The whole rock is red, massive, mainly composed of light red calcite, } \\
\text { bastnäsite and a small amount of quartz composition. The quartz is } \\
\text { randomly distributed, with a content of about } 1 \% \text {. The brown } \\
\text { bastnäsite are discontinuous and banded distributed in red calcite. }\end{array}$ \\
\hline SDW17-4 & Massive ore & 2 & $0.14-5.03$ & 294 & $\begin{array}{l}\text { calcite, barite, } \\
\text { pyrite, fluorite, } \\
\text { bastnäsite }\end{array}$ & $\begin{array}{l}\text { (1) REE-bearing quartz + } \\
\text { fluorite + barite, celestite + } \\
\text { calcite + pyrite, galena, } \\
\text { and sphalerite veins, with } \\
\text { groups of REE-bearing } \\
\text { carbonate veinlets (1-2 mm } \\
\text { wide) making up networks }\end{array}$ & $\begin{array}{l}\text { The massive ore has bastnäsite as the main ore mineral and contains } \\
\text { fluorite, barite, calcite, and with minor pyrite. }\end{array}$ \\
\hline SDW17-6 & $\begin{array}{l}\text { Disseminated } \\
\text { ore }\end{array}$ & 2 & $0.14-5.03$ & 294 & $\begin{array}{l}\text { pyrite, fluorite, } \\
\text { bastnäsite }\end{array}$ & $\begin{array}{l}\text { (1) REE-bearing quartz + } \\
\text { fluorite + barite, celestite + } \\
\text { calcite + pyrite, galena, } \\
\text { and sphalerite veins, with } \\
\text { groups of REE-bearing } \\
\text { carbonate veinlets (1-2 mm } \\
\text { wide) making up networks }\end{array}$ & $\begin{array}{l}\text { The whole is massive, brown, mineral mainly conclude bastnäsite, } \\
\text { fluorite, with a small amount of pyrite. Pyrite is well developed, } \\
\text { smoke gray and granular, local particles larger, up to } 3-8 \mathrm{~cm} \text {, and the } \\
\text { content is about } 5 \% \text {. Fluorite is purple, with content of } 10 \% \text {, randomly } \\
\text { distributed. Containing a small amount of yellowish brown bastnäsite } \\
\text { disseminated in pyrite and fluorite. }\end{array}$ \\
\hline
\end{tabular}



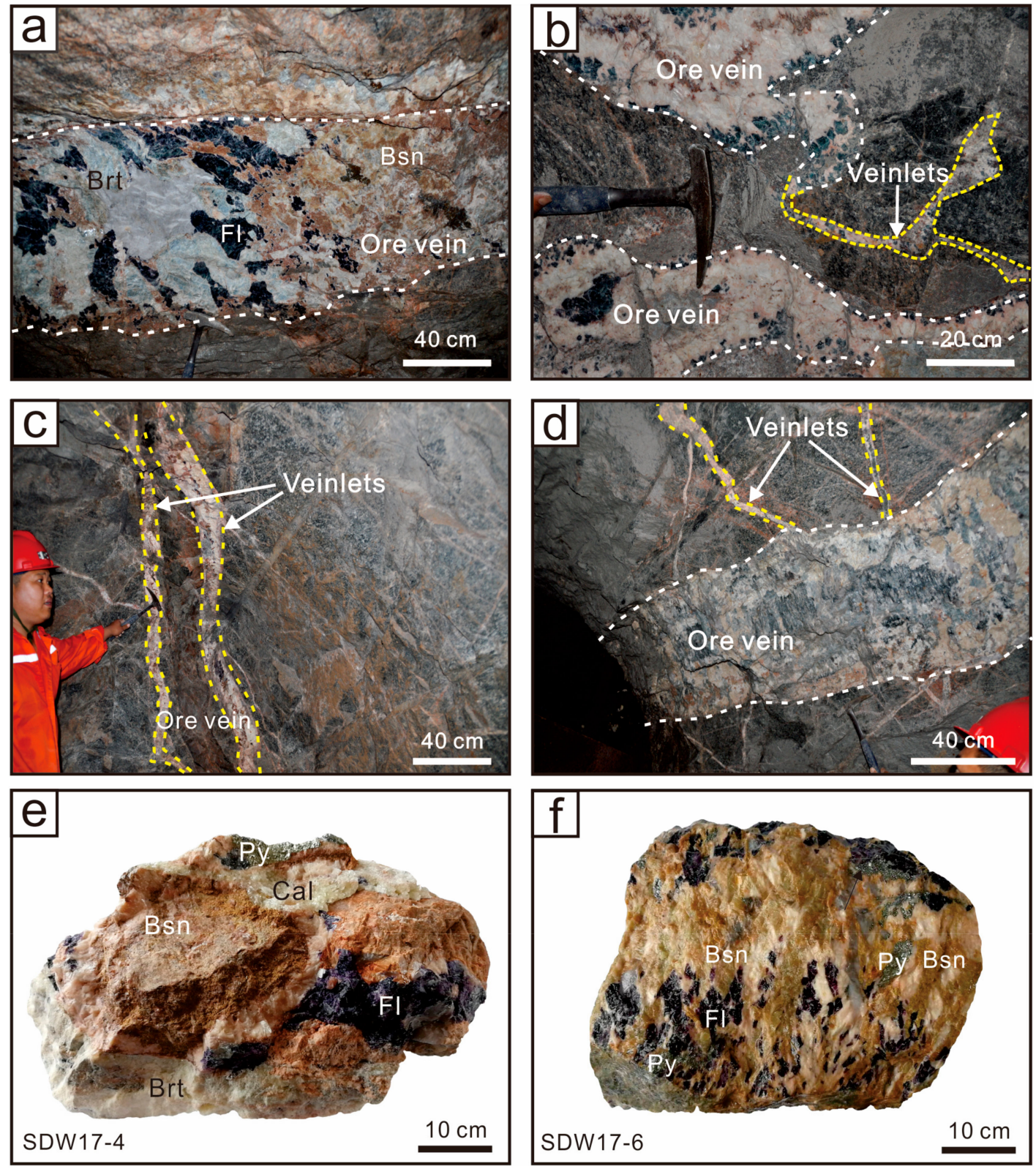

Figure 3. (a-d) Ore veins in the Weishan REE deposit; (e) hand specimen of a typical ore vein containing bastnäsite, barite, calcite, fluorite, quartz, and pyrite; (f) typical ore containing bastnäsite, calcite, fluorite, and pyrite. Bsn = bastnäsite; Brt = Barite; $\mathrm{Cal}=$ calcite; $\mathrm{Fl}=$ fluorite; $\mathrm{Py}=$ pyrite; $\mathrm{Qtz}=$ quartz.

\subsection{Sampling}

Samples SDW16-1, 16-2, 16-3, 16-4, 16-5, and 16-6 comprise REE-bearing quartz + fluorite + barite + celestite + calcite + pyrite + galena + sphalerite and are included in sub-type 1 (Figures 2-5). Sample SDW16-1 comprises mainly gray anhedral quartz ( $\sim 5$ vol. $\%)$, which occurs as randomly distributed 3-5-mm-sized grains (Figure 4a). It also contains rosettes of yellowish brown bastnäsite, which is disseminated in the ores.

Sample SDW16-2 contains pale pink calcite, pale yellow barite, quartz, galena, and minor bastnäsite. Gray anhedral quartz ( 5 vol. \%) occurs as randomly distributed 1-2-mm-sized grains. Yellow-brown bastnäsite occurs as discontinuous bands within white barite and pink calcite (Figure $4 \mathrm{~b}$ ).

Sample SDW16-3 is dominated by pink calcite with minor white calcite, yellow barite, and quartz. Gray quartz (5-10 vol. \%) occurs as randomly distributed 3-6-mm-sized grains. Galena (1-5 vol. \%) occurs 
as narrow veinlets that are 1-10 $\mathrm{cm}$ thick. The sample also contains minor disseminated yellowish brown bastnäsite (Figure 4c).

Sample SDW16-4 comprises mainly calcite ( $\sim 50$ vol. \%) cut by galena veinlets ( $\sim 40$ vol. $\%)$, and minor yellow barite. The veinlets are continuous and contain disseminated pyrite $(\sim 5$ vol. \%) and minor randomly distributed quartz. The pink calcite forms continuous bands within the veins (Figures $3 \mathrm{c}$ and $4 \mathrm{~d}$ ).

Sample SDW16-5 contains pale yellow barite and minor white calcite, pink calcite, and galena. Yellow-brown bastnäsite ( 1 vol. \%) occurs as randomly distributed 1-3-mm-sized grains. Gray galena aggregates $(\sim 10$ vol. $\%)$ occur within a pale green mineral. Some pink calcite, gray euhedral quartz (2-4 mm; 10 vol. \%), granular pyrite (1-2 $\mathrm{mm} ; \sim 5$ vol. \%), and minor muscovite $(<3 \mathrm{~mm})$ are randomly distributed together with barite ( $2-5 \mathrm{~mm} ; \sim 5$ vol. \%) (Figure $4 \mathrm{e})$.

Sample SDW16-6 comprises mainly pale-yellow barite and lesser brown bastnäsite, interspersed with unknown pale green crystals. Granular, xenomorphic, smoky gray quartz crystals (1-4 mm) are also randomly distributed. Some granular pyrite ( 1 vol. \%) occurs on bastnäsite surfaces (Figure $4 \mathrm{f})$.
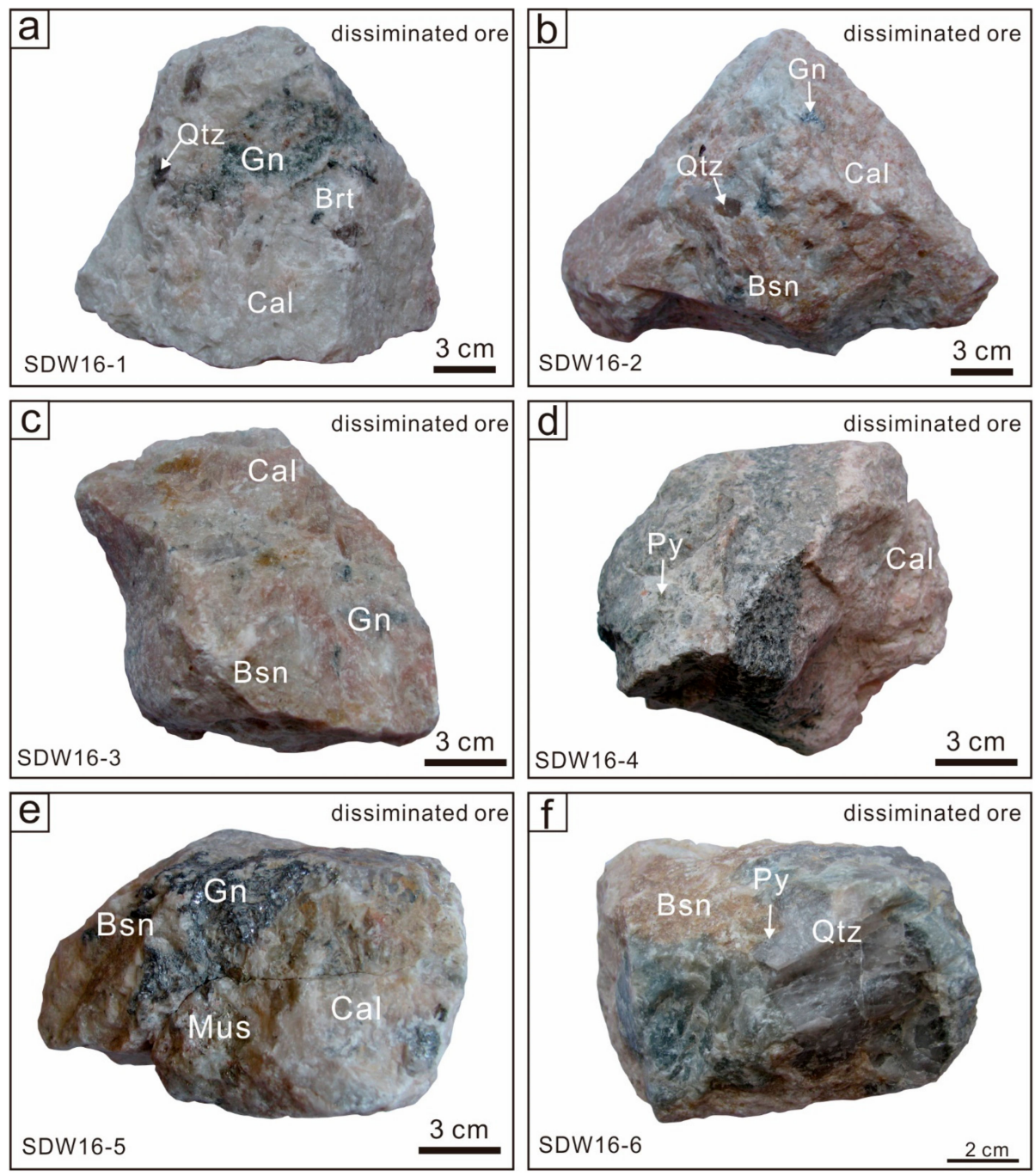

Figure 4. Representative images of ore types in the Weishan REE deposit. (a-d) Massive disseminated ore containing calcite, quartz, barite, galena, and bastnäsite. (b,c,e) Pale red ore containing red calcite, galena, and bastnäsite. (f) Massive ore containing calcite, bastnäsite, and quartz. Bsn = bastnäsite; $\mathrm{Cal}=$ calcite $; \mathrm{Gn}=$ galena; Mus = muscovite $; \mathrm{Py}=$ pyrite $; \mathrm{Qtz}=$ quartz . 
The disseminated ore samples of the Weishan REE deposit (Figure 4) commonly have variable bastnäsite (Figure 5a,b,d,f), parisite (Figure 5a,b,f), monazite (Figure 5c-e), REE-bearing apatite (Figure 5g), and Ca-strontianite (Figure 5g,h) contents. The main gangue minerals are calcite (Figure 5), barite (Figure 5b-e), quartz (Figure 5d-g), phlogopite (Figure 5e), K-feldspar (Figure 5c), albite (Figure 5c), and galena (Figure 5g,i). Bastnäsite, parasite, and other REE minerals were formed in equilibrium with or later than quartz, barite, calcite, and other gangue minerals (Figure 5).
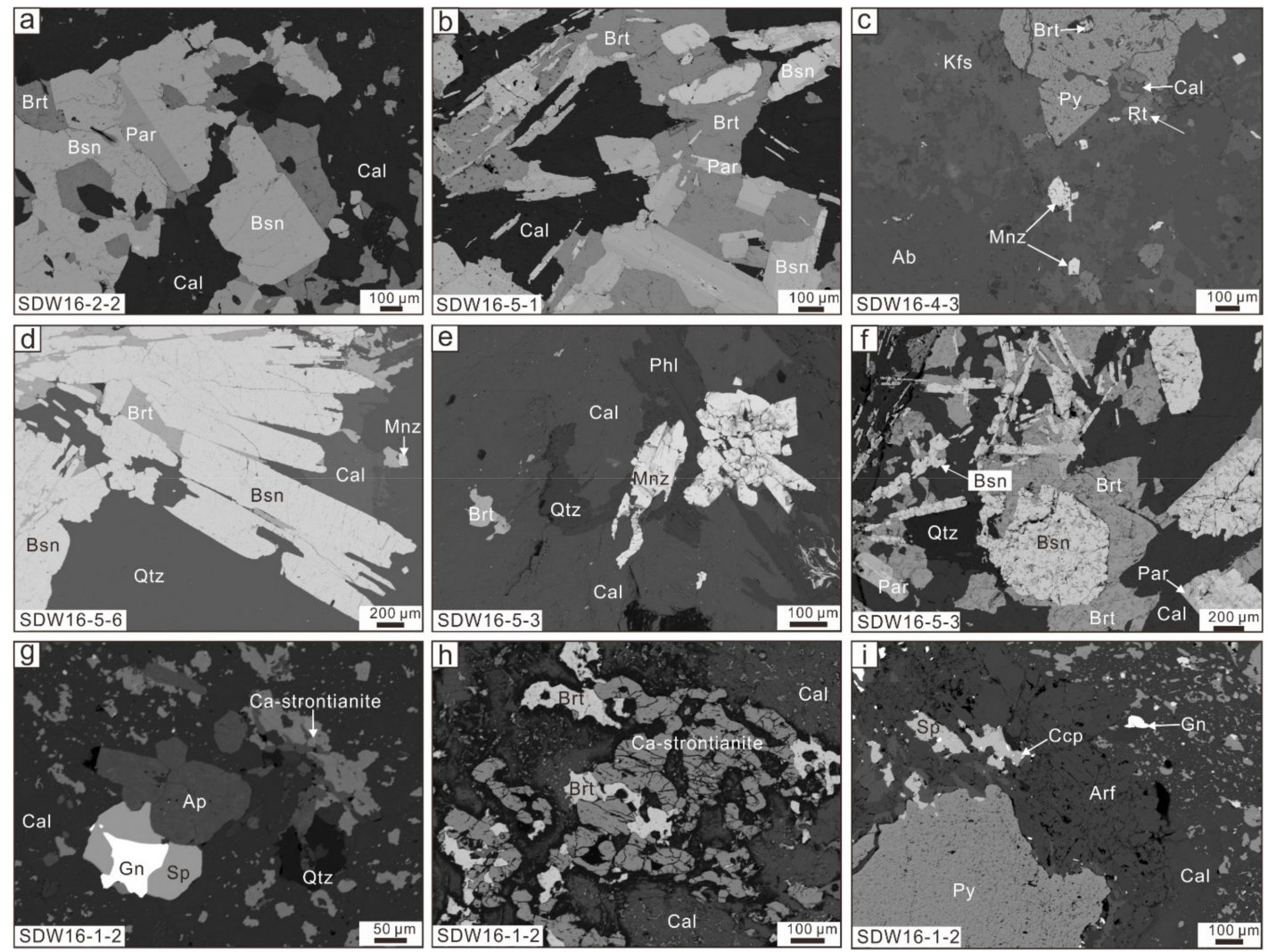

Figure 5. Back-scattered electron images of REE and gangue minerals in the Weishan REE deposit. (a) Bastnäsite and parisite crystallized in equilibrium with calcite; euhedral bastnäsite crystals with parisite on its rims; barite formed after or in equilibrium with bastnäsite and parisite. (b) Bastnäsite and parisite crystallized in equilibrium with calcite and barite. (c) K-feldspar and albite occurring in ores as a relict overprinted by monazite. (d) Euhedral bastnäsite crystals with quartz, calcite, and barite, formed after or in equilibrium with bastnäsite. (e) Xenomorphic monazite overgrowth on quartz, phlogopite, and calcite, suggesting REE mineralization occurred at a later stage than these minerals. (f) Bastnäsite and parisite crystallized in equilibrium with or after calcite and quartz; euhedral bastnäsite crystals formed coevally with parasite, and barite and calcite formed after bastnäsite and parisite. (g) Galena formed coevally with barite and overgrown by sphalerite, quartz, calcite, bastnäsite; barite in equilibrium with galena overgrown by sphalerite; barite overprinted by monazite. (h) Ca-strontianite and barite in equilibrium with calcite. (i) Pyrite, arfvedsonite, and calcite formed coevally and overprinted by sphalerite, chalcopyrite, and galena. $\mathrm{Ab}=$ albite; $\mathrm{Ap}=$ apatite; $\mathrm{Arf}=$ arfvedsonite; Brt = barite; Bsn = bastnäsite; Brt = barite; $\mathrm{Bt}=$ biotite; $\mathrm{Cal}$ = calcite; $\mathrm{Ccp}=$ chalcopyrite; $\mathrm{Gn}$ = galena; Kfs = K-feldspar; Mnz = monazite; Par = parasite; Phl= phlogopite; $\mathrm{Py}=$ pyrite; Qtz = quartz; $\mathrm{Sp}=$ sphalerite

Previous petrological studies [14] and observation of the above typical disseminated ore specimens from the No. 1, No. 2, and No. 4 orebodies have allowed us to determine the paragenetic sequence of minerals within the Weishan deposits (Figure 6), with distinct sequences being associated with an early magmatic stage and a later hydrothermal stage. 


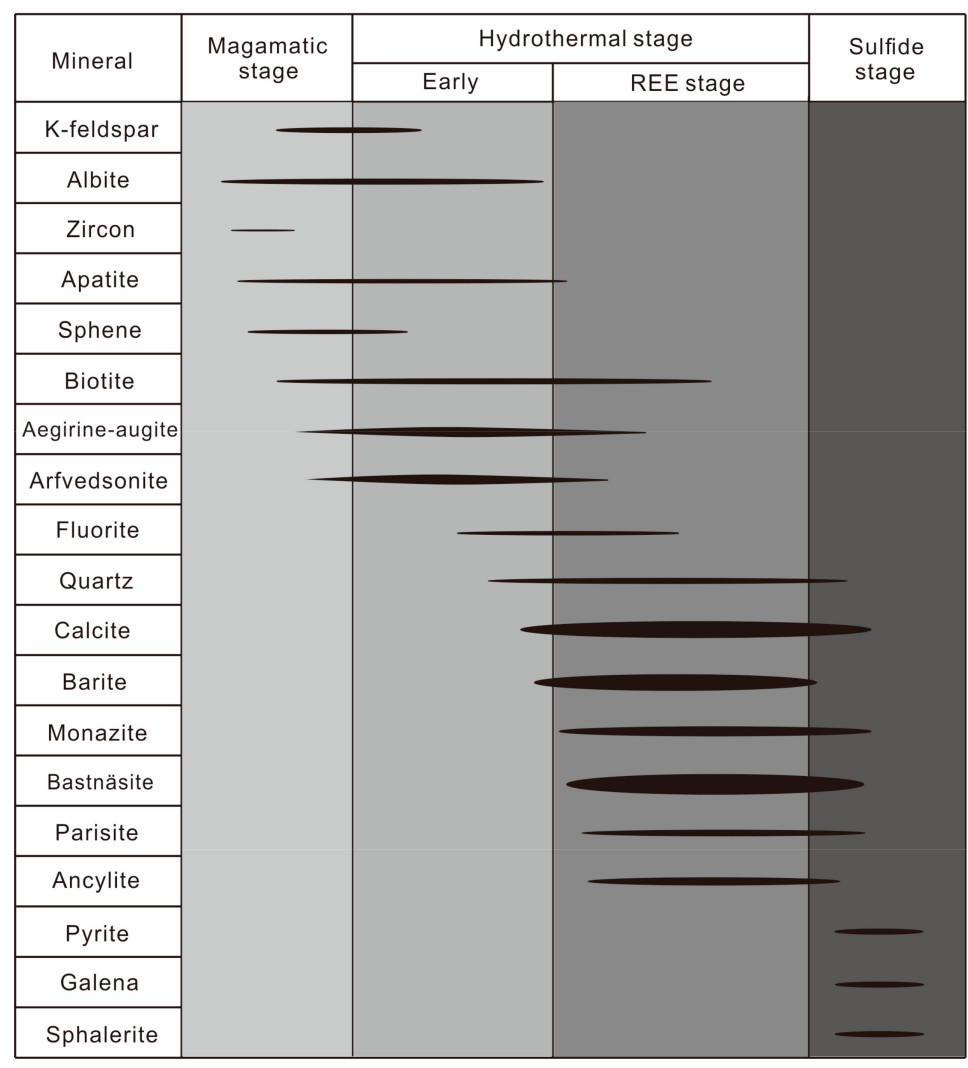

Figure 6. Paragenetic sequence of ore and gangue minerals in the Weishan REE deposit (after [15]).

\section{Analytical Methods}

\subsection{XRD Analyses}

The XRD analyses of ore samples were performed at the Xi'an Geological Survey Center, $\mathrm{i}^{\prime}$ 'an, using Rigaku D/Mac-RC and $\mathrm{Cu} \mathrm{K} \alpha 1$ radiation with a graphite monochromator and continuous scanning under the following operating conditions: voltage $40 \mathrm{kV}$; beam current $80 \mathrm{~mA}$; scanning speed $8^{\circ} \mathrm{min}^{-1}$; slit DS $=\mathrm{SS}=1^{\circ}$; ambient temperature $18^{\circ} \mathrm{C}$; humidity $30 \%$. The contents (wt. \%) of the primary mineral phases identified by the XRD were quantified using an internal standard, with corundum chosen as the reference material. The basic principles and procedures of quantitative analysis using the internal-standard method have been described in detail by $[52,53]$ and the XRD result was listed in Table 3.

\subsection{EPMA Analyses}

Major elements compositions of minerals were determined using a JXA-8230 (Japan Electron Optics Laboratory Co.Lt, Akishima-shi, Japan) electron microprobe at the Institute of Mineral Resources, Chinese Academy of Geological Sciences. Mineralized and barren syenite and carbonatite and typical ore samples were selected from the Weishan REE deposit. A total of 11 samples were selected for systematic chemical analyses. Backscattered electron (BSE) images and mineral compositions were acquired at the Institute of Geology and Geophysics, Chinese Academy of Sciences (IGGCAS), Beijing, China. The operating conditions were accelerating voltage of $15 \mathrm{kV}$ for silicate and oxide, and $20 \mathrm{kV}$ for sulfide, beam current of $20 \mathrm{nA}$, and beam size of $5 \mu \mathrm{m}$. Natural minerals and synthetic oxides were used as standards. Matrix corrections were carried out using the ZAF correction program supplied by the manufacturer [54].

For EPMA, the following standards were used: Jadetite, $\mathrm{Na} \mathrm{K} \alpha$, TAP; forsterite, $\mathrm{Mg} \mathrm{K} \alpha$, TAP; jadetite, $\mathrm{Al} \mathrm{K} \alpha$, TAP; topaz, FK $\alpha$, TAP; K-feldspar, K K $\alpha$, PETG; wollastonite, Ca K $\alpha$, jadetite, SiK, PETJ; 
hematite, Fe K $\alpha$, LIF; rutile, Ti K $\alpha$, LIF; Apatite, PK $\alpha$, PETJ; $\mathrm{Cr}_{2} \mathrm{O}_{3}, \mathrm{Cr} \mathrm{K} \alpha$, LIFH; MnO Mn K $\alpha$, LIFH; $\mathrm{NiO}, \mathrm{Ni} \mathrm{K} \alpha$, LIF; $\mathrm{V}_{2} \mathrm{O}_{5}, \mathrm{VK} \alpha$, LIFH; $\mathrm{NaCl}$; and $\mathrm{Cl} \mathrm{K} \alpha$, PETH. For the determination of REE minerals, phosphates of La, Ce, Pr, Nd, Sm, Eu, Gd, Dy, Ho, Er, Tm, Yb, Lu, and Y; and barium titanate were used as standards for REE analysis. The mineral composition by EPMA was listed in Tables 4 and 5 .

\subsection{In Situ LA-ICP-MS Analyses}

In situ trace element compositions of individual minerals were determined by an excimer $193 \mathrm{~nm}$ ArF Analyte Excite Laser ablation ICP-MS system, coupled to an Agilent 7700x at the FocuMS Technology Co. Ltd., Nanjing, China. This was carried out on the same spots which had been analyzed by EPMA, and the analyzed trace elements include $\mathrm{Rb}, \mathrm{Sr}, \mathrm{Ba}, \mathrm{Ca}, \mathrm{Y}, \mathrm{Th}, \mathrm{U}, \mathrm{Nb}, \mathrm{Ta}, \mathrm{Zr}, \mathrm{Ce}, \mathrm{La}, \mathrm{Pr}, \mathrm{Nd}$, $\mathrm{Sm}, \mathrm{Eu}$. Gd. Tb, Dy, Ho, Er, Tm, Yb, Lu, Hf. The analyses' conditions involved a $7 \mathrm{~Hz}$ repetition rate and a beam diameter of 25-40 $\mu \mathrm{m}$. In addition, BCR-2, BHVO-2, AVG-2, and RGM-2 glasses referred in United States Geological Survey were used as external calibration standards, and Chinese Geological Standard Glasses (CGSG)-1, -2, -4, and -5 (prepared by National Research Center for Geoanalysis, Beijing, China) were treated as quality control [55]. Raw data reduction was performed off-line by ICPMSDataCal software using 100\%-normalization strategy without applying internal standard [56], and the results of the analyses are listed in Table 6.

\subsection{Whole-Rock Geochemistry Analyses}

Major and trace elements compositions of typical ores of Weishan REE deposit were analyzed by wet chemistry and X-ray fluorescence (XRF), ICP-MS, and ICP-atomic emission spectrometry, at the National Research Center of Geoanalysis, CAGS (Beijing, China). Whole-rock geochemical analyses were performed at the National Research Center of Geoanalysis, Chinese Academy of Geological Sciences (CAGS), Beijing, China. Whole-rock powder samples (0.7 g) were mixed with $5.3 \mathrm{~g} \mathrm{Li}_{2} \mathrm{~B}_{4} \mathrm{O}_{7}$, $0.4 \mathrm{~g} \mathrm{LiF}$, and $0.3 \mathrm{~g} \mathrm{NH}_{4} \mathrm{NO}_{3}$ in a $25 \mathrm{~mL}$ porcelain crucible. The powder mixture was transferred to a platinum alloy crucible, $1 \mathrm{~mL}$ LiBr solution was added to the crucible, and the sample was then dried. The sample was then melted in an automatic flame fusion machine and the resulting cooled glass was used for XRF analyses. Analytical errors were $<2 \%$. For trace-element analyses, whole-rock powder samples (50 mg) were dissolved in $1 \mathrm{~mL} \mathrm{HF}$ and $0.5 \mathrm{~mL} \mathrm{HNO}_{3}$ in $15 \mathrm{~mL}^{2}$ Savillex Teflon screw-cap capsules at $190^{\circ} \mathrm{C}$ for 1 day, dried, digested with $0.5 \mathrm{~mL} \mathrm{HNO}_{3}$, and then dried again. The capsule content was digested with $0.5 \mathrm{~mL} \mathrm{HNO}_{3}$ and dried again to ensure complete digestion. Then the sample was digested with $5 \mathrm{~mL} \mathrm{HNO}_{3}$ and sealed at $130{ }^{\circ} \mathrm{C}$ in the oven for $3 \mathrm{~h}$. After cooling, the solution was transferred to a plastic bottle and diluted to $50 \mathrm{~mL}$ before analysis. The sample solutions were analyzed by ICP-MS according to the procedure of State Standard of the Peoples Republic of China (GB): Methods for chemical analysis of silicate rocks-Part 30: Determination of 44 elements (2010). The analytical precision for most elements was better than $5 \%$. To verify the accuracy of the procedure in this study, several standard samples of GBW07120, GBW 07103, GBW 07105, and GBW 07187 were also analyzed together with other samples. As a limestone sample GBW07120 that has low $\mathrm{Zr}$ (11 ppm) and Hf (0.22 ppm) content. The whole-rock major and trace element analyses results were listed in Table 7.

\section{Results}

\subsection{XRD and EPMA Analyses}

XRD and EPMA analyses of typical disseminated ores from veinlets in the Weishan REE deposit indicate that the REE minerals are bastnäsite and parisite (Table 3), with gangue minerals comprising mainly calcite (77.7-89.8 wt. \%), quartz (0.8-9.4 wt. \%), Sr-barite (2.8 wt. \%), Sr-Pb-barite (3.1-4.5 wt. \%), Pb-barite (9.0-14.8 wt. \%) and anatase (2.3-2.5 wt. \%) (Table 3). The different ores have similar gangue and REE mineral assemblages, although the mineral proportions vary. All the REE and gangue mineral compositions of samples SDW16-1-6 were determined by EPMA, with results given in Tables 4 and 5 . 
Table 3. Mineralogy of typical samples from the Weishan, Maoniuping, Dalucao, and Lizhuang REE deposits determined by XRD analyses.

\begin{tabular}{|c|c|c|c|c|}
\hline Sample No. & Deposit & Type & Mineralogy & REE Mineral \\
\hline \multicolumn{5}{|c|}{ Weishan deposit (this study) } \\
\hline SDW17-1-1 & vein 1 & disseminated ores & quartz (9.2 wt. \%), calcite ( 84 wt. \%), Sr-Barite ( 2.8 wt. \%), bastnäsite ( 0.4 wt. \%), Parisite $(0.5$ wt. \%) & bastnäsite, parisite \\
\hline SDW17-1-2 & vein 1 & disseminated ores & quartz $(9.4$ wt. \%), calcite $(85$ wt. $\%), \mathrm{Sr} / \mathrm{Pb}$ Barite $(4.5 \mathrm{wt} . \%)$, bastnäsite $(1.1 \mathrm{wt.} \%)$ & bastnäsite \\
\hline SDW17-1-3 & vein 1 & disseminated ores & quartz ( $(6.6$ wt. \%), calcite $(89.8$ wt. \%), Sr/Pb Barite ( 3.1 wt. \%), bastnäsite $(0.5$ wt. \%) & bastnäsite \\
\hline SDW17-1-4 & vein 1 & disseminated ores & quartz $(3.7$ wt. $\%)$, calcite $(81.9$ wt. $\%)$, Pb-Barite $(9$ wt. $\%$ ), bastnäsite $(1.9$ wt. $\%)$, Parisite $(1$ wt. $\%)$, anatase $(2.5$ wt. $\%)$ & bastnäsite, parisite, anatase \\
\hline SDW17-1-5 & vein 1 & disseminated ores & quartz $(0.8$ wt. $\%)$, calcite $(77.7$ wt. $\%)$, Pb-Barite $(14.8$ wt. $\%)$, bastnäsite $(2.9$ wt. $\%)$, Parisite $(0.5$ wt. $\%)$, anatase $(2.3$ wt. $\%)$ & bastnäsite, parisite, anatase \\
\hline \multicolumn{5}{|c|}{ Deposits in the Mianning-Dechang REE belt (Liu and Hou, 2017) [13] } \\
\hline MNP14-4-1-1 & \multirow{6}{*}{ Maoniuping } & stringer ore & fluorite (49 wt. \%), barite (23 wt. \%), quartz (7 wt. \%), bastnäsite (20 wt. \%) & bastnäsite \\
\hline MNP14-4-1-2 & & powdered stringer ore & fluorite ( 48 wt. $\%)$, barite $(21$ wt. $\%)$, quartz ( 9 wt. $\%)$, bastnäsite ( 22 wt. $\%)$ & bastnäsite \\
\hline MNP14-4-2-1 & & powdered stringer ore & $\begin{array}{l}\text { fluorite }(10 \mathrm{wt} . \%) \text {, biotite }(8 \mathrm{wt.} \%) \text {, quartz ( } 7 \text { wt. \%), feldspar }(4 \mathrm{wt} . \%) \text {, plagioclase ( } 4 \text { wt. \%), barite ( } 2 \text { wt. \%), } \\
\text { bastnäsite }(66 \text { wt. \%) }\end{array}$ & bastnäsite \\
\hline MNP14-4-2-2 & & stringer ore & $\begin{array}{l}\text { fluorite }(10 \text { wt. } \%) \text {, quartz }(8 \mathrm{wt} . \%) \text {, feldspar }(5 \mathrm{wt} . \%) \text {, plagioclase }(4 \mathrm{wt.} \%) \text {, biotite }(3 \mathrm{wt.} \%) \text {, } \\
\text { barite }(1 \mathrm{wt.} \%) \text {, bastnäsite }(70 \text { wt. } \%)\end{array}$ & bastnäsite \\
\hline MNP15-10 & & weathered ore & barite (67 wt. \%), fluorite (18 wt. \%), quartz ( 6 wt. \%), plagioclase ( 2 wt. \%), bastnäsite $(7 \mathrm{wt.} \%)$ & bastnäsite \\
\hline MNP15-11 & & weathered ore & barite $(59$ wt. $\%)$, fluorite $(22$ wt. $\%)$, quartz (12 wt. $\%)$, plagioclase ( 2 wt. $\%)$,feldspar $(0-1$ wt. $\%)$, bastnäsite $(5$ wt. $\%)$ & bastnäsite \\
\hline DLC11-9 & \multirow{4}{*}{ Dalucao } & carbonatite & \multirow{4}{*}{ 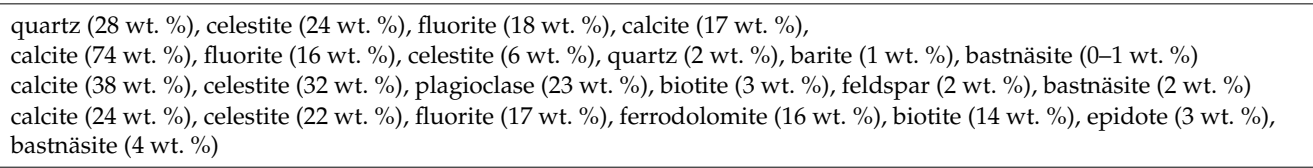 } & bastnäsite \\
\hline DLC11-17 & & carbonatite & & bastnäsite \\
\hline DLC11-63-2 & & ore vein & & bastnäsite \\
\hline DLC15-3-2 & & ore vein & & bastnäsite \\
\hline LZ11-1-4 & \multirow{8}{*}{ Lizhuang } & carbonatite & calcite $(61 \mathrm{wt} . \%)$, barytocelestite ( $36 \mathrm{wt} . \%)$, biotite $(3 \mathrm{wt} . \%)$, bastnäsite $(0-1 \mathrm{wt} . \%)$ & bastnäsite \\
\hline LZ11-1-7 & & carbonatite & calcite $(52 \mathrm{wt.} \%)$, barytocelestite $(43 \mathrm{wt} . \%)$, biotite ( $5 \mathrm{wt} . \%)$, fluorite $(0-1 \mathrm{wt} . \%)$, bastnäsite $(0-1 \mathrm{wt} . \%)$ & bastnäsite \\
\hline LZ11-1-8 & & carbonatite & calcite $(70 \mathrm{wt.} \%)$, barytocelestite $(25 \mathrm{wt.} \%)$, biotite $(5 \mathrm{wt.} \%)$, fluorite ( $0-1 \mathrm{wt.} \%)$, bastnäsite $(0-1 \mathrm{wt.} \%)$ & bastnäsite \\
\hline LZ1 & & brecciated ore & $\begin{array}{l}\text { calcite }(76 \text { wt. } \%) \text {, fluorite }(14 \text { wt. } \%) \text {, barite ( } 3 \text { wt. } \%) \text {, mica }(3 \text { wt. } \%) \text {, quartz }(2 \text { wt. } \%) \text {, } \\
\text { graphite }(0-1 \text { w. } \%) \text {, bastnäsite }(2 \text { wt. } \%)\end{array}$ & bastnäsite \\
\hline LZ3 & & brecciated ore & 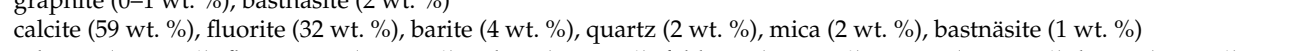 & bastnäsite \\
\hline LZ5 & & ore vein & $\begin{array}{l}\text { celestite }(31 \text { wt. \%), fluorannite ( } 23 \text { wt. \%), calcite ( } 21 \text { wt. \%), feldspar (11 wt. \%), quartz }(9.0 \text { wt. \%), barite ( } 3 \text { wt. \%), } \\
\text { bastnäsite }(2 \text { wt. \%) }\end{array}$ & bastnäsite \\
\hline LZ6 & & altered syenite & feldspar (30 wt. \%), biotite ( $28 \mathrm{wt} . \%)$, quartz (18 wt. \%), plagioclase (16 wt. \%), calcite (6 wt. \%), bastnäsite ( $2 \mathrm{wt.} \%)$ & bastnäsite \\
\hline LZ14-3 & & massive ore & quartz $(47 \mathrm{wt.} \%)$, calcite $(29 \mathrm{wt.} \%)$, fluorite $(7 \mathrm{wt.} \%)$, biotite $(7 \mathrm{wt.} \%)$, pyrite $(5 \mathrm{wt.} \%)$, bastnäsite $(6 \mathrm{wt.} \%)$ & bastnäsite \\
\hline
\end{tabular}


Table 4. Compositions of representative REE-bearing minerals formed during the hydrothermal stage in the Weishan REE deposit.

\begin{tabular}{|c|c|c|c|c|c|c|c|c|c|c|c|c|c|c|c|c|c|c|c|c|c|c|c|}
\hline Comment & Spots & Mineral & $F$ & $\mathrm{Na}_{2} \mathrm{O}$ & $\mathrm{MgO}$ & $\mathrm{Al}_{2} \mathrm{O}_{3}$ & $\mathrm{~K}_{2} \mathrm{O}$ & $\mathrm{SiO}_{2}$ & $\mathrm{P}_{2} \mathrm{O}_{5}$ & $\mathrm{Y}_{2} \mathrm{O}_{3}$ & $\mathrm{ThO}_{2}$ & $\mathrm{Sm}_{2} \mathrm{O}_{3}$ & $\mathrm{CaO}$ & $\mathrm{TiO}_{2}$ & $\mathrm{FeO}$ & $\mathrm{Pr}_{2} \mathrm{O}_{3}$ & $\mathrm{Nd}_{2} \mathrm{O}_{3}$ & $\mathrm{Yb}_{2} \mathrm{O}_{3}$ & $\mathrm{Ta}_{2} \mathrm{O}_{5}$ & $\mathrm{La}_{2} \mathrm{O}_{3}$ & $\mathrm{Ce}_{2} \mathrm{O}_{3}$ & $\mathrm{UO}_{2}$ & Total \\
\hline SDW16-6-1 & 1 & Ancylite & 0.28 & 0.00 & 0.00 & 0.00 & 0.00 & 0.00 & 0.02 & 0.00 & 0.00 & 0.00 & 0.57 & 0.00 & 0.00 & 3.92 & 3.46 & 0.00 & 0.15 & 12.94 & 29.28 & 0.00 & 50.34 \\
\hline SDW16-6-1 & 2 & 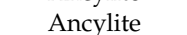 & 0.67 & 0.00 & 0.00 & 0.00 & 0.00 & 0.00 & 0 & 0 & & & 0.58 & 0.00 & 0.03 & 4.26 & 3.05 & 0 & .00 & 3.67 & 29.60 & 0.09 & 51.28 \\
\hline SDW16-6-1 & 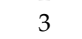 & Ancylite & & ח & 0.00 & 0.00 & 0.00 & & ח & 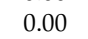 & م & 0.32 & 0.35 & 0.00 & 0.02 & 3.96 & 3.90 & 0 & .07 & 2.46 & 30.92 & 0.00 & 52.00 \\
\hline SDW16-1-2 & 1 & at & 5.31 & 0.90 & 0.00 & 0.00 & 0.02 & 0.00 & 37.29 & & 0.02 & 0.00 & 42.01 & 0.00 & 0.00 & 0.24 & 1.22 & 0.01 & 00 & .55 & 2.04 & 0.00 & 83.38 \\
\hline SDW16-1-2 & 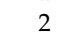 & & & 071 & 0.02 & & 0.00 & & 38.35 & & & & 45.51 & 0.00 & 0.00 & 038 & & & .00 & 0.26 & 2.02 & 0.00 & 87.80 \\
\hline SDW16-1-2 & 3 & atte & 4.71 & 1.10 & 0.02 & 0.00 & 0.07 & 0.30 & 36.79 & & 0 & & 40.47 & & 0.00 & 0.42 & & & & 0.94 & 96 & 0.00 & 84.57 \\
\hline & 1 & & & 0.00 & 0.00 & & 0.00 & & & & & & & & & & & & & & & 0.01 & 65.80 \\
\hline SDW1 & 1 & & 5.30 & 0 & 0. & & 0. & & & & & & & & 0.00 & & & & 0 & 30 & 30 & 0.10 & 66.60 \\
\hline SDI & 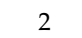 & & & & 0.0 & & 0.00 & & & & & & 0.90 & & 0.00 & & & & 00 & & 50 & 0.00 & 62.80 \\
\hline SDW16-6-2 & 3 & Bstnäsite & 7.90 & 0.00 & 0.00 & 0.00 & 0.00 & 0.00 & 0.00 & 0.00 & 0.00 & 0.20 & 0.70 & 0.00 & 0.00 & 5.90 & 3.30 & 0.00 & 0.00 & 25.20 & 28.70 & 0.00 & 64.20 \\
\hline Comment & Spots & Mineral & F & $\mathrm{Na}_{2} \mathrm{O}$ & $\mathrm{MgO}$ & $\mathrm{Al}_{2} \mathrm{O}_{3}$ & $\mathrm{~K}_{2} \mathrm{O}$ & $\mathrm{SiO}_{2}$ & $\mathrm{P}_{2} \mathrm{O}_{5}$ & $\mathrm{Y}_{2} \mathrm{O}_{3}$ & $\mathrm{TiO}_{2}$ & $\mathrm{Sm}_{2} \mathrm{O}_{3}$ & $\mathrm{CaO}$ & SrO & $\mathrm{FeO}$ & $\mathrm{Pr}_{2} \mathrm{O}_{3}$ & $\mathrm{Nd}_{2} \mathrm{O}_{3}$ & $\mathrm{Yb}_{2} \mathrm{O}_{3}$ & $\mathrm{Ta}_{2} \mathrm{O}_{5}$ & $\mathrm{La}_{2} \mathrm{O}_{3}$ & $\mathrm{Ce}_{2} \mathrm{O}_{3}$ & $\mathrm{UO}_{2}$ & Total \\
\hline SDW16- & 1 & -stro & 0.1 & 0.23 & 0.00 & 0.00 & 0.03 & 0.00 & 0.0 & 0. & 0. & 0.00 & 16.05 & 24.25 & 0.0 & 1.9 & 1.5 & 0.0 & 0.00 & 7.48 & 5.91 & 0.02 & 67.33 \\
\hline & 1 & & & & 0.00 & & 0.00 & & & & & & 15.98 & 28.74 & 0.00 & & & & 0 & 4 & 13.94 & 0.00 & 68.00 \\
\hline SDW16-1-2 & 2 & a-strontianite & 0.00 & 0.00 & 0.00 & 0.00 & 0.02 & 0.00 & 0.01 & 0.00 & 0.00 & 0.00 & 9.27 & 59.68 & 0.00 & 0.00 & 0.13 & 0.00 & 0.00 & 0.00 & 0.19 & 0.00 & 69.30 \\
\hline SDW16-1-2 & 1 & Ca-strontianite & 0.13 & 0.28 & 0.00 & 0.01 & 0.05 & 0.00 & 0.00 & 0.00 & 0.00 & 0.00 & 16.29 & 24.21 & 0.01 & 2.57 & 1.29 & 0.00 & 0.00 & 6.11 & 13.46 & 0.00 & 63.99 \\
\hline Comment & Spots & Mineral & $F$ & $\mathrm{Cl}$ & $\mathrm{Na}_{2} \mathrm{O}$ & $\mathrm{MgO}$ & $\mathrm{Al}_{2} \mathrm{O}_{3}$ & $\mathrm{~K}_{2} \mathrm{O}$ & $\mathrm{P}_{2} \mathrm{O}_{5}$ & $\mathrm{Y}_{2} \mathrm{O}_{3}$ & $\mathrm{Gd}_{2} \mathrm{O}_{3}$ & $\mathrm{TiO}_{2}$ & $\mathrm{Sm}_{2} \mathrm{O}_{3}$ & $\mathrm{CaO}$ & $\mathrm{TiO}_{2}$ & $\mathrm{FeO}$ & $\mathrm{Pr}_{2} \mathrm{O}_{3}$ & $\mathrm{Nd}_{2} \mathrm{O}_{3}$ & $\mathrm{Ta}_{2} \mathrm{O}_{5}$ & $\mathrm{La}_{2} \mathrm{O}_{3}$ & $\mathrm{Ce}_{2} \mathrm{O}_{3}$ & $\mathrm{UO}_{2}$ & Total \\
\hline SDW16-3 & 1 & ristite & 6.86 & 0.14 & 0.00 & 0.00 & 0.00 & 0.00 & 0.02 & 0.29 & 4.34 & 0.00 & 0.94 & 11.31 & 0.00 & 0.01 & 4.14 & 5.94 & 0.00 & 12.62 & 30.20 & 0.00 & 76.80 \\
\hline & 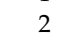 & & & & 0.00 & & 0.07 & & & & & & & & & & & & 0 & 8.12 & 75 & 0.00 & 78.96 \\
\hline SDW16-3 & 3 & & 5.79 & 0.07 & 0.00 & 0.00 & 0.00 & 0. & 0. & 0. & 2. & 0.0 & 0.85 & 9.90 & 0.00 & 0.0 & 3. & 4.8 & 0.00 & 14.31 & 34.77 & 0.00 & 76.93 \\
\hline SDW16-3 & 4 & Bstnäsite & 8.67 & 0.06 & 0.00 & 0.00 & 0.00 & 0.01 & 0.00 & 0.06 & 3.37 & 0.00 & 0.52 & 0.10 & 0.00 & 0.00 & 3.89 & 4.42 & 0.00 & 14.28 & 38.21 & 0.00 & 73.58 \\
\hline
\end{tabular}

Table 5. Compositions of representative gangue minerals formed during the hydrothermal stage in the Weishan deposit.

\begin{tabular}{|c|c|c|c|c|c|c|c|c|c|c|c|c|c|c|c|c|c|c|c|c|c|}
\hline SamplesNo. & Spots & Mineral & $\mathrm{SiO}_{2}$ & $\mathrm{TiO}_{2}$ & $\mathrm{Al}_{2} \mathrm{O}_{3}$ & $\mathrm{FeO}$ & $\mathrm{MgO}$ & $\mathrm{CaO}$ & $\mathrm{Na}_{2} \mathrm{O}$ & $\mathrm{K}_{2} \mathrm{O}$ & $\mathrm{P}_{2} \mathrm{O}_{5}$ & F & $\mathrm{Cl}$ & $\mathrm{BaO}$ & $\mathrm{SrO}$ & $\mathrm{ThO}_{2}$ & $\mathrm{ZrO}_{2}$ & $\mathrm{SO}_{3}$ & $\mathrm{UO}_{2}$ & $\mathrm{Ta}_{2} \mathrm{O}_{5}$ & Total \\
\hline SDW16-5-6 & 1 & Phlogopite & 55.44 & 0.11 & 3.11 & 0.32 & 22.57 & 0.02 & 0.14 & 10.16 & 0.01 & 3.71 & 0.01 & 0.00 & 2.42 & 0.00 & 0.00 & 0.00 & 0.00 & 0.00 & 98.03 \\
\hline SDW16-5-6 & 2 & Phlogopite & 56.56 & 0.01 & 2.76 & 0.33 & 22.66 & 0.01 & 0.11 & 10.18 & 0.00 & 3.54 & 0.01 & 0.02 & 0.44 & 0.02 & 0.00 & 0.00 & 0.00 & 0.00 & 96.66 \\
\hline SDW16-5-6 & 3 & Phlogopite & 56.62 & 0.05 & 2.41 & 0.24 & 22.18 & 0.11 & 0.11 & 9.92 & 0.00 & 3.72 & 0.00 & 0.01 & 0.48 & 0.06 & 0.01 & 0.00 & 0.00 & 0.00 & 95.92 \\
\hline SDW16-5-6 & 4 & Phlogopite & 58.80 & 0.02 & 1.91 & 0.18 & 22.89 & 0.07 & 0.12 & 10.05 & 0.01 & 4.39 & 0.01 & 0.00 & 2.44 & 0.06 & 0.07 & 0.03 & 0.00 & 0.00 & 101.06 \\
\hline SDW16-5-3 & 1 & Phlogopite & 54.16 & 0.02 & 2.93 & 0.14 & 20.71 & 0.06 & 0.07 & 10.21 & 0.00 & 3.76 & 0.00 & 0.00 & 0.44 & 0.00 & 0.03 & 0.01 & 0.00 & 0.00 & 92.54 \\
\hline SDW16-5-6 & 1 & Sr-rich barite & 0.00 & 0.17 & 0.04 & 0.07 & 0.00 & 0.25 & 0.03 & 0.02 & 0.00 & 0.21 & 0.00 & 22.75 & 40.15 & 0.00 & 0.06 & 32.80 & 0.00 & 0.00 & 96.54 \\
\hline SDW16-5-5 & 1 & Sr-rich barite & 0.00 & 0.15 & 0.02 & 0.04 & 0.00 & 0.21 & 0.10 & 0.02 & 0.01 & 0.03 & 0.00 & 21.49 & 42.36 & 0.00 & 0.02 & 32.87 & 0.00 & 0.00 & 97.32 \\
\hline SDW16-5-3 & 1 & Sr-rich barite & 0.00 & 0.02 & 0.00 & 0.02 & 0.00 & 0.22 & 0.04 & 0.01 & 0.00 & 0.00 & 0.00 & 17.19 & 47.37 & 0.09 & 0.00 & 34.19 & 0.02 & 0.00 & 99.16 \\
\hline SDW16-1-2 & 1 & Aegirine & 51.47 & 0.76 & 0.51 & 22.10 & 2.03 & 3.18 & 10.96 & 0.00 & 0.01 & 0.21 & 0.01 & 0.05 & 0.46 & 0.04 & 0.04 & 0.00 & 0.00 & 0.00 & 91.81 \\
\hline SDW16-1-2 & 2 & Aegirine & 51.94 & 0.40 & 0.40 & 24.26 & 0.96 & 1.64 & 12.14 & 0.00 & 0.01 & 0.00 & 0.00 & 0.08 & 0.43 & 0.12 & 0.04 & 0.03 & 0.02 & 0.00 & 92.47 \\
\hline SDW16-1-2 & 3 & Aegirine & 51.47 & 1.98 & 0.40 & 21.07 & 2.13 & 3.03 & 10.99 & 0.00 & 0.03 & 0.00 & 0.06 & 0.05 & 0.47 & 0.00 & 0.03 & 0.04 & 0.00 & 0.00 & 91.74 \\
\hline SDW16-1-2 & 4 & Aegirine & 53.12 & 0.52 & 0.40 & 21.56 & 2.59 & 4.36 & 10.93 & 0.00 & 0.00 & 0.00 & 0.01 & 0.00 & 2.13 & 0.00 & 0.04 & 0.03 & 0.04 & 0.00 & 95.72 \\
\hline SDW16-6-3 & 1 & Calcite & 0.00 & 0.00 & 0.00 & 0.34 & 0.30 & 49.96 & 0.06 & 0.00 & 0.03 & 0.02 & 0.01 & 0.02 & 4.51 & 0.09 & 0.00 & 0.04 & 0.01 & 0.00 & 55.38 \\
\hline SDW16-6-3 & 2 & Calcite & 0.00 & 0.01 & 0.00 & 0.03 & 0.38 & 53.73 & 0.07 & 0.01 & 0.01 & 0.04 & 0.00 & 0.06 & 1.35 & 0.01 & 0.00 & 0.00 & 0.00 & 0.04 & 55.74 \\
\hline SDW16-5-3 & 1 & Calcite & 0.00 & 0.00 & 0.00 & 0.14 & 0.40 & 52.48 & 0.04 & 0.00 & 0.01 & 0.14 & 0.00 & 0.00 & 1.61 & 0.00 & 0.08 & 0.01 & 0.04 & 0.00 & 54.94 \\
\hline
\end{tabular}


Table 5. Cont.

\begin{tabular}{|c|c|c|c|c|c|c|c|c|c|c|c|c|c|c|c|c|c|c|c|c|c|}
\hline SamplesNo. & Spots & Mineral & $\mathrm{SiO}_{2}$ & $\mathrm{TiO}_{2}$ & $\mathrm{Al}_{2} \mathrm{O}_{3}$ & $\mathrm{Cr}_{2} \mathrm{O}_{3}$ & $\mathrm{FeO}$ & $\mathrm{MnO}$ & $\mathrm{MgO}$ & $\mathrm{CaO}$ & $\mathrm{Na}_{2} \mathrm{O}$ & $\mathrm{K}_{2} \mathrm{O}$ & $\mathrm{P}_{2} \mathrm{O}_{5}$ & F & $\mathrm{SrO}$ & $\mathrm{SO}_{3}$ & $\mathrm{BaO}$ & $\mathrm{Cl}$ & $\mathrm{NiO}$ & $\mathrm{V}_{2} \mathrm{O}_{3}$ & Total \\
\hline SDW16-3 & 3 & Calcite & 0.00 & 0.00 & 0.01 & 0.00 & 0.18 & 0.66 & 0.40 & 52.98 & 0.00 & 0.01 & 0.01 & 0.00 & 1.66 & 0.00 & 0.03 & 0.00 & 0.00 & 0.02 & 55.94 \\
\hline SDW16-3 & 4 & Calcite & 0.01 & 0.00 & 0.01 & 0.02 & 0.20 & 0.55 & 0.30 & 53.66 & 0.03 & 0.00 & 0.00 & 0.00 & 1.42 & 0.02 & 0.00 & 0.00 & 0.01 & 0.00 & 56.22 \\
\hline SDW16-3 & 5 & Calcite & 0.02 & 0.00 & 0.00 & 0.04 & 0.00 & 0.44 & 0.27 & 53.06 & 0.02 & 0.00 & 0.00 & 0.00 & 1.93 & 0.05 & 0.00 & 0.00 & 0.04 & 0.02 & 55.88 \\
\hline SDW16-6-2 & 1 & Calcite & 0.01 & 0.00 & 0.01 & 0.02 & 0.07 & 0.48 & 0.39 & 53.16 & 0.02 & 0.00 & 0.05 & 0.08 & 2.52 & 0.03 & 0.00 & 0.00 & 0.02 & 0.00 & 56.84 \\
\hline SDW16-6-2 & 2 & Calcite & 0.01 & 0.01 & 0.01 & 0.05 & 0.20 & 0.44 & 0.50 & 52.86 & 0.06 & 0.00 & 0.03 & 0.00 & 1.97 & 0.01 & 0.06 & 0.00 & 0.01 & 0.01 & 56.22 \\
\hline SDW16-6-2 & 3 & Calcite & 0.01 & 0.00 & 0.00 & 0.00 & 0.14 & 0.35 & 0.46 & 52.56 & 0.03 & 0.00 & 0.02 & 0.00 & 3.29 & 0.01 & 0.00 & 0.00 & 0.01 & 0.00 & 56.87 \\
\hline SDW16-3 & 1 & Celestite & 0.02 & 0.27 & 0.07 & 0.04 & 0.00 & 0.04 & 0.01 & 0.19 & 0.03 & 0.04 & 0.00 & 0.00 & 34.07 & 41.18 & 24.07 & 0.00 & 0.00 & 0.00 & 100.02 \\
\hline SDW16-3 & 2 & Celestite & 0.00 & 0.23 & 0.03 & 0.08 & 0.00 & 0.00 & 0.00 & 0.14 & 0.04 & 0.00 & 0.00 & 0.00 & 35.25 & 41.17 & 22.07 & 0.01 & 0.02 & 0.00 & 99.03 \\
\hline SDW16-6-2 & 1 & Celestite & 0.02 & 0.22 & 0.04 & 0.00 & 0.01 & 0.07 & 0.02 & 0.14 & 0.00 & 0.01 & 0.00 & 0.15 & 38.07 & 42.21 & 18.74 & 0.00 & 0.00 & 0.00 & 99.70 \\
\hline SDW16-6-2 & 2 & Celestite & 0.00 & 0.28 & 0.06 & 0.03 & 0.01 & 0.00 & 0.00 & 0.13 & 0.03 & 0.02 & 0.00 & 0.00 & 32.08 & 41.58 & 25.58 & 0.01 & 0.00 & 0.00 & 99.81 \\
\hline SDW16-6-2 & 3 & Celestite & 0.04 & 0.21 & 0.04 & 0.00 & 0.01 & 0.00 & 0.01 & 0.16 & 0.09 & 0.01 & 0.00 & 0.10 & 36.67 & 40.59 & 22.26 & 0.00 & 0.00 & 0.00 & 100.20 \\
\hline SDW16-3 & 1 & Quartz & 99.23 & 0.03 & 0.06 & 0.00 & 0.00 & 0.00 & 0.01 & 0.02 & 0.00 & 0.00 & 0.00 & 0.00 & 0.10 & 0.04 & 0.00 & 0.00 & 0.00 & 0.00 & 99.49 \\
\hline SDW16-3 & 2 & Quartz & 98.40 & 0.00 & 0.05 & 0.04 & 0.00 & 0.00 & 0.00 & 0.01 & 0.00 & 0.00 & 0.00 & 0.00 & 0.81 & 0.02 & 0.03 & 0.00 & 0.00 & 0.02 & 99.37 \\
\hline SDW16-4 & 1 & Quartz & 98.54 & 0.00 & 0.00 & 0.00 & 0.06 & 0.00 & 0.00 & 0.04 & 0.02 & 0.02 & 0.01 & 0.00 & 0.83 & 0.02 & 0.00 & 0.00 & 0.00 & 0.00 & 99.53 \\
\hline SDW16-4 & 1 & K-feldspar & 65.05 & 0.05 & 18.06 & 0.01 & 0.34 & 0.00 & 0.00 & 0.00 & 0.45 & 13.38 & 0.00 & 0.00 & 2.78 & 0.03 & 0.17 & 0.00 & 0.01 & 0.03 & 100.34 \\
\hline SDW16-4 & 2 & K-feldspar & 64.47 & 0.00 & 18.80 & 0.02 & 0.27 & 0.01 & 0.00 & 0.01 & 0.14 & 14.59 & 0.00 & 0.00 & 0.57 & 0.00 & 0.16 & 0.00 & 0.01 & 0.04 & 99.09 \\
\hline SDW16-4 & 3 & K-feldspar & 64.38 & 0.00 & 18.30 & 0.04 & 0.13 & 0.02 & 0.00 & 0.04 & 0.19 & 15.46 & 0.03 & 0.00 & 0.49 & 0.03 & 0.02 & 0.01 & 0.00 & 0.03 & 99.15 \\
\hline SDW16-4 & 1 & Albite & 68.39 & 0.01 & 18.92 & 0.00 & 0.00 & 0.00 & 0.00 & 0.11 & 11.36 & 0.08 & 0.00 & 0.00 & 0.59 & 0.03 & 0.00 & 0.00 & 0.02 & 0.00 & 99.50 \\
\hline SDW16-4 & 2 & Albite & 66.30 & 0.00 & 19.10 & 0.00 & 0.01 & 0.00 & 0.01 & 0.25 & 11.04 & 0.12 & 0.00 & 0.00 & 2.99 & 0.02 & 0.04 & 0.00 & 0.01 & 0.00 & 99.88 \\
\hline SDW16-4 & 1 & Apatite & 0.02 & 0.00 & 0.00 & 0.00 & 0.02 & 0.00 & 0.03 & 50.17 & 0.64 & 0.00 & 41.40 & 2.93 & 4.13 & 0.23 & 0.00 & 0.02 & 0.00 & 0.00 & 99.60 \\
\hline SDW16-1 & 1 & Apatite & 0.04 & 0.00 & 0.01 & 0.00 & 0.22 & 0.00 & 0.02 & 50.12 & 0.54 & 0.00 & 40.43 & 2.47 & 4.25 & 0.07 & 0.00 & 0.01 & 0.00 & 0.02 & 98.17 \\
\hline SDW16-1 & 2 & Aegirine & 49.33 & 0.55 & 0.59 & 0.14 & 25.05 & 0.07 & 0.79 & 1.49 & 12.94 & 0.01 & 0.05 & 0.31 & 2.18 & 0.04 & 0.02 & 0.00 & 0.00 & 0.17 & 93.72 \\
\hline SDW16-1 & 3 & Aegirine & 52.10 & 3.64 & 0.39 & 0.00 & 23.27 & 0.20 & 1.78 & 2.57 & 12.05 & 0.00 & 0.01 & 0.09 & 0.47 & 0.00 & 0.03 & 0.00 & 0.00 & 0.13 & 96.73 \\
\hline SDW16-1 & 1 & Rutile & 0.03 & 96.18 & 0.00 & 0.01 & 1.65 & 0.05 & 0.00 & 0.02 & 0.00 & 0.00 & 0.00 & 0.07 & 0.00 & 0.04 & 0.61 & 0.00 & 0.00 & 1.16 & 99.82 \\
\hline SDW16-4 & 1 & Barite & 0.12 & 0.61 & 1.04 & 0.04 & 0.12 & 0.00 & 0.01 & 0.11 & 0.09 & 0.00 & 0.00 & 0.00 & 10.67 & 36.24 & 51.10 & 0.00 & 0.00 & 0.00 & 100.14 \\
\hline SDW16-1 & 1 & Barite & 0.00 & 0.64 & 0.22 & 0.01 & 0.15 & 0.00 & 0.00 & 0.11 & 0.09 & 0.00 & 0.00 & 0.00 & 4.37 & 35.46 & 58.71 & 0.00 & 0.00 & 0.00 & 99.76 \\
\hline SDW16-1 & 2 & Barite & 0.10 & 0.70 & 0.10 & 0.06 & 0.78 & 0.00 & 0.01 & 0.07 & 0.08 & 0.00 & 0.00 & 0.00 & 4.93 & 36.59 & 56.17 & 0.00 & 0.00 & 0.00 & 99.59 \\
\hline SamplesNo. & Spots & Mineral & Se & As & $\mathrm{Ge}$ & $\mathrm{Zn}$ & $\mathrm{S}$ & $\mathrm{Pb}$ & Bi & $\mathrm{Hg}$ & $\mathrm{Fe}$ & $\mathrm{Cu}$ & $\mathrm{Sb}$ & Co & $\mathrm{Ag}$ & $\mathrm{Au}$ & $\mathrm{Te}$ & $\mathrm{Ni}$ & Total & & \\
\hline SDW16- & 1 & $\therefore$ & 0.00 & , & 0 & , & 52.8 & 0.01 & 0.00 & , & 463 & 0 & 0 & 0. & 0 & 0 & 0.0 & 0.00 & 99.20 & & \\
\hline SDW16-4 & 2 & Pyrite & 0.02 & 0.00 & 0.00 & 0.00 & 53.30 & 0.05 & 0.00 & 0.00 & 45.90 & 0.02 & 0.02 & 0.04 & 0.00 & 0.01 & 0.01 & 0.00 & 99.30 & & \\
\hline SDW16-4 & 3 & Pyrite & 0.00 & 0.01 & 0.00 & 0.00 & 53.20 & 0.02 & 0.00 & 0.00 & 45.90 & 0.04 & 0.00 & 0.00 & 0.00 & 0.00 & 0.02 & 0.00 & 99.20 & & \\
\hline SDW16-4 & 1 & sphalerite & 0.00 & 0.00 & 0.00 & 67.40 & 32.50 & 0.05 & 0.08 & 0.00 & 0.07 & 0.01 & 0.00 & 0.02 & 0.00 & 0.00 & 0.00 & 0.00 & 100.00 & & \\
\hline SDW16-4 & 1 & galena & 0.02 & 0.00 & 0.23 & 0.00 & 13.50 & 86.00 & 0.00 & 0.05 & 0.00 & 0.00 & 0.00 & 0.00 & 0.10 & 0.00 & 0.09 & 0.00 & 99.90 & & \\
\hline SDW16-1 & 1 & galer & 0.00 & 0.00 & 0.19 & 0.00 & 13.40 & 85.80 & 0.00 & 0.08 & 0.13 & 0.00 & 0.00 & 0.00 & 0.00 & 0.00 & 0.01 & 0.02 & 99.60 & & \\
\hline SDW16-5-2 & 1 & galena & 0.00 & 0.00 & 0.22 & 0.00 & 13.30 & 85.40 & 0.00 & 0.04 & 0.01 & 0.01 & 0.00 & 0.00 & 0.00 & 0.00 & 0.08 & 0.01 & 99.00 & & \\
\hline
\end{tabular}


Table 6. Results of LA-ICP-MS analyses (in ppm) of barite, calcite, strontianite, bastnäsite, and monazite from typical REE ores in the Weishan deposit.

\begin{tabular}{|c|c|c|c|c|c|c|c|c|c|c|c|c|c|c|c|c|c|c|c|c|c|c|c|c|c|c|c|}
\hline Sample No. & Spots & Minerals & $\mathbf{R b}$ & $\mathrm{Sr}$ & $\bar{Y}$ & Th & $\mathrm{U}$ & $\mathrm{Nb}$ & $\mathrm{Ta}$ & $\mathrm{Zr}$ & $\mathbf{L a}$ & $\mathrm{Ce}$ & $\operatorname{Pr}$ & $\mathrm{Nd}$ & Sm & Eu & Gd & $\mathrm{Tb}$ & Dy & Ho & Er & $\mathrm{Tm}$ & $\mathrm{Yb}$ & $\mathrm{Lu}$ & $\mathrm{Hf}$ & इREE & $(\mathrm{La} / \mathrm{Yb})_{\mathrm{N}}$ \\
\hline \multirow{5}{*}{ SWD16-2-2 } & 1 & Brt & 0.1 & 200,028 & 3.16 & 0 & 0.15 & 0 & 0 & 0 & 74.3 & 21.4 & 0.57 & 0.58 & 0.2 & 5.51 & 0.43 & 0 & 0 & 0 & 0 & 0 & 0.02 & 0.01 & 0.17 & 103 & 3552 \\
\hline & 2 & Brt & 0.11 & 238,738 & 3.2 & 0 & 0.21 & 0 & 0 & 0.01 & 126 & 36.4 & 0.83 & 1.13 & 0.14 & 5.32 & 0.58 & 0 & 0.01 & 0 & 0 & 0.01 & 0.03 & 0.01 & 0.09 & 171 & 3224 \\
\hline & 3 & Brt & 0.06 & 194,134 & 3.12 & 0 & 0.03 & 0 & 0 & 0 & 160 & 49 & 1.17 & 1.46 & 0.16 & 5.3 & 0.38 & 0 & 0 & 0 & 0 & 0 & 0.07 & 0.02 & 0.05 & 217 & 1655 \\
\hline & 4 & Brt & 0.06 & 198,366 & 3.45 & 0 & 0.15 & 0.01 & 0 & 0 & 92 & 26.3 & 0.63 & 0.59 & 0.24 & 5.48 & 0.48 & 0 & 0.01 & 0 & 0 & 0 & 0.02 & 0.01 & 0.11 & 126 & 2958 \\
\hline & 5 & Brt & 0.11 & 179,802 & 3.52 & 0 & 0.24 & 0.01 & 0 & 0 & 121 & 34.9 & 0.86 & 1.02 & 0.24 & 5.79 & 0.41 & 0.02 & 0.01 & 0 & 0 & 0 & 0.04 & 0.01 & 0.08 & 165 & 1963 \\
\hline \multirow{3}{*}{ SWD16-1-2 } & 1 & $\mathrm{Cal}$ & 0.17 & 56,183 & 223 & 0 & 0.01 & 0 & 0.01 & 0 & 80.7 & 281 & 46.1 & 252 & 88.3 & 29.9 & 86.3 & 10.8 & 50.8 & 8.46 & 18.9 & 2.4 & 13.7 & 1.66 & 0 & 971 & 4.24 \\
\hline & 2 & $\mathrm{Cal}$ & 0.11 & 58,529 & 238 & 0.05 & 0.09 & 0.08 & 0.01 & 9.51 & 341 & 1039 & 143 & 690 & 164 & 44.7 & 108 & 12 & 54 & 8.99 & 20 & 2.35 & 13.9 & 1.57 & 0.17 & 2641 & 17.5 \\
\hline & 3 & $\mathrm{Cal}$ & 0.28 & 62,915 & 211 & 0.01 & 0.87 & 0.01 & 0 & 0.08 & 47.2 & 184 & 32 & 187 & 77.3 & 26.5 & 74.1 & 9.3 & 46.3 & 7.82 & 18.8 & 2.32 & 13.2 & 1.71 & 0.01 & 728 & 2.56 \\
\hline \multirow{8}{*}{ SWD16-2-2 } & 1 & $\mathrm{Cal}$ & 0.1 & 15,310 & 268 & 0.03 & 0.02 & 0 & 0 & 0.01 & 196 & 427 & 45.6 & 207 & 61 & 20.1 & 58.8 & 9.6 & 52.6 & 9.46 & 23.2 & 3.01 & 18.7 & 2.38 & 0.02 & 1134 & 7.54 \\
\hline & 2 & $\mathrm{Cal}$ & 0.09 & 25,075 & 282 & 0.21 & 0.12 & 0 & 0 & 0 & 329 & 702 & 72.4 & 329 & 95.1 & 30.4 & 80.5 & 11 & 55.8 & 10 & 23.7 & 3.18 & 19.7 & 2.35 & 0.01 & 1763 & 12 \\
\hline & 3 & $\mathrm{Cal}$ & 0.04 & 17,792 & 289 & 0 & 0 & 0 & 0 & 0.01 & 260 & 722 & 81.1 & 305 & 52.8 & 14.3 & 32.7 & 5.85 & 38.2 & 7.57 & 17.8 & 2.12 & 10.9 & 1.11 & 0.01 & 1552 & 17.1 \\
\hline & 4 & $\mathrm{Cal}$ & 0.15 & 14,534 & 271 & 0.02 & 0.12 & 0 & 0.01 & 0.01 & 311 & 648 & 62.6 & 302 & 84.9 & 27.4 & 77.4 & 10.4 & 55.7 & 10.1 & 24.3 & 3.41 & 19 & 2.35 & 0 & 1638 & 11.7 \\
\hline & 5 & $\mathrm{Cal}$ & 0.08 & 8329 & 331 & 0.01 & 0.04 & 0 & 0 & 0 & 60.6 & 155 & 17.7 & 76 & 22 & 7.73 & 23.8 & 5.66 & 41.4 & 9.68 & 27.7 & 4.03 & 22.6 & 2.55 & 0.02 & 476 & 1.93 \\
\hline & 6 & $\mathrm{Cal}$ & 0.11 & 9908 & 303 & 0.01 & 0.03 & 0 & 0 & 0 & 157 & 407 & 50.7 & 218 & 52.9 & 16.2 & 46 & 7.86 & 48.7 & 9.43 & 24.7 & 3.17 & 19 & 2.29 & 0 & 1063 & 5.91 \\
\hline & 7 & $\mathrm{Cal}$ & 0.04 & 24,431 & 304 & 0.03 & 0.06 & 0 & 0 & 0 & 242 & 569 & 66.6 & 283 & 69.8 & 22.7 & 65.4 & 9.53 & 54.4 & 10 & 24.9 & 3.25 & 20.2 & 2.49 & 0 & 1444 & 8.62 \\
\hline & 8 & $\mathrm{Cal}$ & 0.05 & 21,645 & 328 & 0.01 & 0.04 & 0 & 0 & 0 & 316 & 830 & 105 & 423 & 93.9 & 27.3 & 74.7 & 11 & 58 & 9.86 & 23.3 & 2.74 & 16.5 & 1.84 & 0 & 1993 & 13.8 \\
\hline \multirow{3}{*}{ SWD16-2-3 } & 1 & $\mathrm{Cal}$ & 0.11 & 30,439 & 398 & 0.06 & 0.78 & 0.01 & 0 & 0.01 & 281 & 635 & 63.6 & 282 & 86.7 & 30.5 & 88.5 & 13.8 & 72.9 & 12.3 & 28.6 & 3.57 & 22.2 & 2.93 & 0 & 1624 & 9.07 \\
\hline & 2 & $\mathrm{Cal}$ & 1.68 & 5319 & 116 & 0.02 & 0.11 & 0.03 & 0 & 0.16 & 9.25 & 26.1 & 3.78 & 22 & 11.3 & 4.85 & 15.9 & 3.05 & 19.3 & 3.71 & 10 & 1.63 & 12.8 & 2.44 & 0.05 & 146 & 0.52 \\
\hline & 3 & Cal & 0.03 & 7270 & 147 & 0.01 & 0.05 & 0 & 0 & 0 & 10.9 & 35.6 & 5.66 & 32.1 & 14.1 & 6.16 & 19.2 & 3.82 & 23.8 & 4.5 & 12.8 & 2.05 & 16.5 & 2.96 & 0.01 & 190 & 0.47 \\
\hline \multirow[b]{2}{*}{ SWD16-5-6 } & 1 & $\mathrm{Cal}$ & 0.12 & 17,195 & 276 & 0 & 0.04 & 0.42 & 0 & 0.12 & 152 & 439 & 55.7 & 257 & 66.3 & 22.1 & 60.1 & 9.37 & 49.4 & 8.79 & 22.2 & 2.91 & 16.8 & 2.01 & 0 & 1164 & 6.5 \\
\hline & 2 & Cal & 0.16 & 23,012 & 262 & 0 & 0.05 & 0 & 0 & 0 & 219 & 571 & 73 & 312 & 71.6 & 21.9 & 60.8 & 8.92 & 48.9 & 8.78 & 20.9 & 2.79 & 16.5 & 1.95 & 0 & 1438 & 9.53 \\
\hline \multirow{4}{*}{ SWD16-3-2 } & 1 & C & 0.01 & 12,340 & 332 & 60.2 & 0.48 & 0.03 & 0 & 0 & 4544 & 5923 & 505 & 162 & 212 & 50.2 & 12 & 13.6 & 63.4 & 10.9 & 25 & 3.23 & 18.3 & 2.11 & 0.02 & 13,120 & 178 \\
\hline & 2 & $\mathrm{Cal}$ & 0.05 & 15,231 & 357 & 0.01 & 0.04 & 0.01 & 0 & 0 & 73.7 & 256 & 41.1 & 212 & 84 & 28.7 & 81.2 & 12.2 & 64 & 11.7 & 28.1 & 3.58 & 19.5 & 2.47 & 0 & 918 & 2.71 \\
\hline & 3 & $\mathrm{Cal}$ & 0.09 & 16102 & 351 & 0.42 & 0.03 & 0 & 0 & 0 & 214 & 589 & 79.4 & 379 & 110 & 34.5 & 94.3 & 13.3 & 68 & 12.1 & 27.7 & 3.6 & 19.3 & 2.28 & 0.01 & 1646 & 7.93 \\
\hline & 4 & $\mathrm{Cal}$ & 0.06 & 12,863 & 357 & 0.01 & 0.02 & 0 & 0 & 0 & 108 & 331 & 44.7 & 205 & 73.7 & 25.1 & 71.2 & 11.4 & 62.1 & 10.9 & 27 & 3.46 & 19.3 & 2.19 & 0.02 & 996 & 4.02 \\
\hline \multirow{3}{*}{ SWD16-1-2 } & 1 & 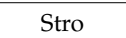 & 0.05 & 537,675 & 119 & 0.7 & 11.2 & 0.06 & 0 & 0.6 & 47 & 1275 & 0 & 812 & 166 & 40.4 & 91.6 & 9.01 & 34.2 & 4.76 & 9.72 & 0.91 & 5.04 & 0.65 & 0 & 3094 & 67 \\
\hline & 2 & Stro & 0 & 54,663 & 1078 & 8.69 & 20.3 & 0.29 & 0 & 2.06 & 2051 & 6156 & 875 & 4368 & 1129 & 308 & 924 & 95.4 & 362 & 45.1 & 69.8 & 5.39 & 20.7 & 1.88 & 0.09 & 16,412 & 71.2 \\
\hline & 3 & Stro & 0.39 & 5936 & 3.04 & 0.19 & 0.34 & 6.45 & 0.03 & 509 & 52.9 & 99.2 & 7.73 & 25.8 & 3.13 & 0.97 & 1.53 & 0.17 & 0.63 & 0.09 & 0.3 & 0.08 & 1.59 & 0.39 & 7.55 & 194 & 23.9 \\
\hline \multirow{8}{*}{ SWD16-5-6 } & 1 & Bsn & 0.29 & 1682 & 305 & 580 & 4 & 0.01 & 0 & 0.43 & 374,508 & 367,267 & 25,859 & 66462 & 3483 & 531 & 1136 & 53.7 & 112 & 9.86 & 14.9 & 0.54 & 1.28 & 0.12 & 0.03 & 839,439 & 209,589 \\
\hline & 2 & Bsn & 0.05 & 1559 & 215 & 643 & 4.19 & 0.02 & 0.01 & 0.36 & 383,863 & 366710 & 24,624 & 60430 & 2806 & 437 & 966 & 43 & 83.8 & 6.87 & 11.5 & 0.36 & 0.83 & 0.09 & 0.02 & 839,982 & 331,285 \\
\hline & 3 & Bsn & 0.14 & 1558 & 253 & 586 & 8.06 & 0.02 & 0.01 & 0.39 & 370,862 & 375,039 & 25,652 & 63962 & 2825 & 420 & 913 & 40.8 & 85.8 & 7.61 & 12.6 & 0.38 & 0.95 & 0.09 & 0.01 & 839,821 & 278,989 \\
\hline & 4 & Bsn & 0.02 & 1777 & 254 & 1060 & 3.05 & 0.02 & 0.01 & 0.33 & 348,443 & 382,006 & 27,690 & 74216 & 3986 & 567 & 1177 & 51.3 & 99.1 & 8.59 & 14.2 & 0.5 & 1.29 & 0.11 & 0.02 & 838,259 & 193,924 \\
\hline & 5 & Bsn & 0.34 & 729 & 208 & 445 & 6.69 & 0.03 & 0.01 & 0.39 & 383,365 & 366,195 & 24,894 & 62676 & 2799 & 423 & 952 & 42.5 & 84.7 & 6.76 & 10.5 & 0.29 & 0.65 & 0.06 & 0.02 & 841,450 & 421,240 \\
\hline & 6 & Bsn & 0.04 & 1218 & 180 & 206 & 6.12 & 0.03 & 0 & 0.46 & 373,758 & 376,053 & 25,349 & 62350 & 2646 & 381 & 848 & 36 & 67.8 & 5.79 & 9.73 & 0.29 & 0.65 & 0.07 & 0.01 & 841,505 & 410,178 \\
\hline & 7 & Bsn & 0.2 & 1931 & 165 & 760 & 4.1 & 0.02 & 0 & 0.38 & 364,327 & 375,906 & 26,661 & 68092 & 2878 & 399 & 843 & 34.5 & 65.7 & 5.55 & 9.99 & 0.3 & 0.7 & 0.09 & 0 & 839,222 & 375,898 \\
\hline & 8 & Bsn & 0 & 2609 & 245 & 1549 & 3.14 & 0.04 & 0.01 & 0.59 & 363,296 & 375,990 & 25,982 & 67643 & 3751 & 546 & 1147 & 50.7 & 98.8 & 8.64 & 13.5 & 0.47 & 1.19 & 0.1 & 0.01 & 838,530 & 219,599 \\
\hline
\end{tabular}


Table 6. Cont.

\begin{tabular}{|c|c|c|c|c|c|c|c|c|c|c|c|c|c|c|c|c|c|c|c|c|c|c|c|c|c|c|c|}
\hline Sample No. & pots & linerals & $\mathbf{R b}$ & Sr & $Y$ & Th & $\mathrm{U}$ & $\mathrm{Nb}$ & Ta & $\mathrm{Zr}$ & La & $\mathrm{Ce}$ & Pr & Nd & Sm & Eu & Gd & $\mathrm{Tb}$ & Dy & Ho & Er & $\mathrm{Tm}$ & $\mathrm{Yb}$ & Lu & $\mathrm{Hf}$ & $\Sigma$ REE & $(\mathrm{La} / \mathrm{Yb})_{\mathrm{N}}$ \\
\hline \multirow{5}{*}{ SWD16-6-5 } & 1 & Bsn & 01 & 365 & 557 & 189 & 13 & 0.03 & 0.01 & 44 & 377,376 & 5,813 & 5,027 & 9577 & 2886 & 511 & 1167 & 71.3 & 181 & 15.2 & 20 & 0.76 & 1.57 & 0.12 & 0.05 & 842,647 & 172,445 \\
\hline & 2 & & & 80 & 306 & 40 & 7.11 & & 0 & & 8430 & &, 796 & & 23 & 458 & 1021 & 51.6 & 111 & 82 & 12.1 & 33 & 0.75 & 0.07 & 0.02 & & \\
\hline & 3 & & & $-5=0$ & 446 & 113 & 10.7 & & 0 & & & & & & & 515 & 46 & 64.9 & & 2.6 & & 57 & 1.12 & & 02 & & \\
\hline & 4 & & & 833 & 349 & 172 & 1.98 & 0.02 & م & & 371,632 & 7338 & & 097 & 10 & 448 & 17 & 54.9 & 122 & 10 & 11 & 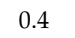 & 1.26 & 0.11 & .02 & & \\
\hline & 5 & Bsn & 04 & 872 & 320 & 213 & 4.85 & 0.02 & 0 & 0.43 & 367,550 & 381,794 & 25,450 & 2321 & 916 & 488 & 1089 & 54.7 & 118 & 9.27 & 13.3 & 0.37 & 0.87 & 0.09 & 0 & 841,806 & 302,290 \\
\hline \multirow{5}{*}{ SWD16-6-4 } & 1 & $\operatorname{Ben}$ & .07 & 22 & 199 & 1813 & 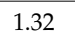 & 0.02 & 0.01 & 0.41 & 52 & 365,358 & 77 & 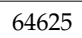 & 14 & 422 & 923 & 41.2 & .4 & 62 & 10.6 & 28 & .88 & 0.07 & 0 & J & 95 \\
\hline & 2 & & & & 593 & 279 & & & & & & & & & & 54 & 11 & 75.6 & 7 & & 8 & & 34 & 0.11 & 0.02 & & \\
\hline & 3 & & & 834 & 867 & 331 & 11.5 & & 0.01 & & & & & & & 582 & & 88.3 & & & & & 73 & 0.14 & 03 & & \\
\hline & 4 & & & 654 & 1109 & 597 & 17.5 & 0.07 & 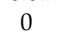 & 35 & 35 & 378 & 6,566 & & 98 & 621 & 13 & 105 & 300 & 26.8 & 29.6 & 1.05 & 1.97 & 0.13 & 0.04 & & \\
\hline & 5 & Bsn & 06 & 680 & 613 & 315 & 7.24 & 0.03 & 0.01 & 0.44 & 366,701 & 371,857 & 26,624 & 0476 & 4199 & 704 & 1519 & 87.3 & 204 & 17.6 & 21.2 & 0.74 & 1.88 & 0.12 & 0.04 & 42,414 & 139,618 \\
\hline \multirow[b]{2}{*}{ SWD16-5-4 } & 1 & & & 739 & 6 & 398 & 10.4 & 5 & 0.01 & 33 & 0,108 & 380,1 &, 164 & \pm & 22 & 480 & 1031 & 64.2 & 172 & 5.8 & 19.2 & 0.64 & 1.2 & 0.11 & 0.03 & & \\
\hline & 2 & Bsn & 0.05 & 623 & 759 & 742 & 23.5 & 0.02 & 0 & 0.43 & 380,195 & 371,695 & 25,013 & 60833 & 2659 & 405 & 876 & 49.8 & 146 & 16.1 & 24.8 & 1.25 & 3.06 & 0.2 & 0.01 & 841,917 & 9,248 \\
\hline \multirow{4}{*}{ SWD1 } & & & & & 19 & 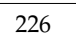 & 10.3 & 3 & & 0.49 & 375,08 & 7663 & 384 & 6197 & 8 & 392 & 81 & 39 & 80.2 & .2 & 8.6 & 8 & 0.44 & 0.05 & 0.02 & & 10 \\
\hline & 2 & & 3 & & 1 & & . & & 0.01 & & & & & & & & & 38.2 & 4 & & 9 & & 49 & 04 & & & \\
\hline & 3 & & 0 & 1459 & 522 & 320 & 15.9 & & 0 & 0.46 & & & & & & 470 & & 62 & 164 & 14.3 & 17.3 & 0.65 & 1.29 & 0.11 & 0.06 & & \\
\hline & 4 & Bsn & 0.05 & 541 & 332 & 181 & 12.4 & 0.02 & 0 & 0.38 & 368,045 & 377,817 & 26,304 & 66153 & 3011 & 450 & 942 & 48.8 & 116 & 9.77 & 12.2 & 0.38 & 0.62 & 0.07 & 0.03 & 842,908 & 423,290 \\
\hline \multirow{5}{*}{ SWD16-4-3 } & 1 & & & 332 & 480 & 1923 & 79 & 1.54 & & 1.24 & 9,924 & 11 & 23,240 & 1848 & 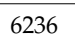 & 1066 & 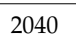 & 12 & 277 & 21.8 & 26 & 0.99 & 2.5 & 0.2 & 0.04 & 575,998 & \\
\hline & 2 & & & 1669 & 4 & 5 & 76.9 & & 0.01 & & & & & & & & & 1 & & & & & & & & & \\
\hline & 3 & & & reto & 52 & & & & 0.01 & & & & & & & 1170 & & 13 & & & & & 3 & 2 & & & \\
\hline & 4 & & & & - & & & & 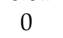 & & & & & & & & & 1 & & & & & & & & & \\
\hline & 5 & IIII & 11 & 2499 & 553 & 2049 & $\pi$ & 6.79 & 0 & 0.95 & 17 & 2 & 31 & 00 & 6009 & 1033 & 2046 & 128 & 302 & 4.2 & 30.2 & 1.69 & 6.69 & 0.79 & .05 & 91 & 15 \\
\hline SWD16-2-2 & 1 & Mnz & 0.05 & 18,518 & 429 & 918 & 93.6 & 3.26 & 0.01 & 0.42 & 172,585 & 256,122 & 22,471 & 72415 & 6505 & 1032 & 2062 & 115 & 256 & 20.8 & 25.8 & 0.98 & 2.53 & 0.19 & 0.02 & 533,611 & 48,994 \\
\hline \multirow[b]{2}{*}{ SWD16-5-6 } & 1 & & & 254 & 4 & 46 & 10 & 0 & 0 & $x$ & & 267,004 & , & 3 & 3 & 6 & 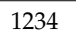 & 79 & 2. & & 22.2 & 1 & 89 & 27 & 3 & & 68 \\
\hline & 2 & Mnz & 0.12 & 2271 & 463 & 692 & 96.4 & 0.03 & 0 & 0.42 & 209,498 & 275,283 &, 577 & 60793 & 4450 & 735 & 1513 & 97.2 & 252 & 20.9 & 23.6 & 0.87 & 1.6 & 0.12 & 0.02 & 574,245 & 93,809 \\
\hline \multirow{3}{*}{ SWD16-1-2 } & 2 & & 0 & 1720 & 37.9 & 0. & 62 & 1 & 0. & 33 & & & & & 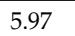 & 1 & 6.39 & 1. & 7.26 & 1.32 & 0 & 0.5 & 56 & 65 & 0 & & \\
\hline & 3 & & & 264 & & 0. & 4 & & & & & & & & & & & & & & & & & & 1.48 & & \\
\hline & 4 & Par & 0.45 & 796 & 14.1 & 0.08 & 0.02 & 0.29 & 0.08 & 544 & 5.43 & 12.2 & 1.71 & 8.99 & 3.14 & 0.93 & 3.31 & 0.62 & 2.82 & 0.57 & 1.13 & 0.16 & 1.68 & 0.48 & 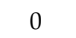 & 43.2 & 2.32 \\
\hline
\end{tabular}

Notes: $\mathrm{Brt}=$ barite; $\mathrm{Bsn}=$ bastnäsite $; \mathrm{Cal}=$ calcite; $\mathrm{Fl}=$ fluorite; $\mathrm{Mnz}=$ monazite; $\mathrm{Str}=$ strontianite; $\mathrm{Par}=$ parisite 
Table 7. Whole-rock geochemical compositions of typical REE ores in the Weishan deposit.

\begin{tabular}{|c|c|c|c|c|c|c|c|c|}
\hline Samples & SDW17-1 & SDW17-2 & SDW17-3 & SDW17-4 & SDW17-6 & SDW16-4 & SDW16-5 & Average \\
\hline $\mathrm{SiO}_{2}$ & 1.07 & 5.7 & 0.62 & 0.37 & 2.56 & 13.68 & 3.6 & 7.89 \\
\hline $\mathrm{Al}_{2} \mathrm{O}_{3}$ & 0.25 & 0.41 & 0.25 & 0.25 & 0.25 & 0.25 & 0.36 & 0.58 \\
\hline $\mathrm{CaO}$ & 41.05 & 33.9 & 39.37 & 40.52 & 22.57 & 35.52 & 24.04 & 33.9 \\
\hline $\mathrm{Fe}_{2} \mathrm{O}_{3}$ & 0.1 & 0.1 & 0.1 & 0.1 & 0.17 & 7.49 & 0.89 & 0.11 \\
\hline $\mathrm{FeO}$ & 0.31 & 0.38 & 0.18 & 0.16 & 1.26 & 0.88 & 0.23 & 0.26 \\
\hline $\mathrm{K}_{2} \mathrm{O}$ & 0.02 & 0.42 & 0.01 & 0.02 & 0.01 & 0.02 & 0.22 & 0.1 \\
\hline $\mathrm{MgO}$ & 0.09 & 0.08 & 0.11 & 0.06 & 0.16 & 0.33 & 0.86 & 0.24 \\
\hline $\mathrm{MnO}$ & 0.52 & 0.58 & 0.53 & 0.38 & 0.49 & 0.75 & 0.66 & 0.56 \\
\hline $\mathrm{Na}_{2} \mathrm{O}$ & 0.2 & 0.53 & 0.35 & 0.57 & 1.03 & 0.05 & 0.04 & 0.4 \\
\hline $\mathrm{P}_{2} \mathrm{O}_{5}$ & 0.21 & 0.18 & 0.27 & 0.17 & 0.48 & 0.93 & 0.48 & 0.39 \\
\hline $\mathrm{TiO}_{2}$ & 0.01 & 0.01 & 0.01 & 0 & 0.08 & 0.39 & 0.02 & 0.07 \\
\hline $\mathrm{CO}_{2}$ & 35.95 & 30.59 & 32.82 & 34.28 & 22.97 & 20.13 & 20.74 & 28.2 \\
\hline $\mathrm{H}_{2} \mathrm{O}^{+}$ & 0.66 & 1.65 & 1.31 & 1.15 & 1.42 & 1.49 & 1.12 & 1.26 \\
\hline Total & 80.44 & 74.53 & 75.93 & 78.03 & 53.45 & 81.91 & 53.26 & 73.96 \\
\hline $\mathrm{Li}$ & 5.56 & 2.42 & 2.48 & 1.95 & 2.52 & 7.36 & 196 & 31.2 \\
\hline $\mathrm{Be}$ & 0.15 & 0.47 & 0.13 & 0.07 & 0.15 & 0.27 & 2.11 & 0.48 \\
\hline $\mathrm{Cr}$ & 1.99 & 2.89 & 0.26 & 0.12 & 4.58 & 39.4 & 1.43 & 7.24 \\
\hline $\mathrm{Mn}$ & 2758 & 3336 & 3068 & 2067 & 3280 & 5470 & 3685 & 3381 \\
\hline Co & 0.49 & 0.99 & 0.3 & 0.26 & 13.2 & 16.9 & 2.12 & 4.89 \\
\hline $\mathrm{Ni}$ & 7.83 & 6.83 & 6.95 & 5.06 & 8.6 & 15.3 & 5.56 & 8.02 \\
\hline $\mathrm{Cu}$ & 1.22 & 2.89 & 0.54 & 0.17 & 22.7 & 57.1 & 0.69 & 12.2 \\
\hline $\mathrm{Zn}$ & 5.28 & 397 & 4.63 & 3.02 & 478 & 149 & 542 & 225.6 \\
\hline $\mathrm{Ga}$ & 0.83 & 0.63 & 0.27 & 0.13 & 0.87 & 2.69 & 0.69 & 0.87 \\
\hline $\mathrm{Rb}$ & 0.68 & 5.13 & 0.4 & 0.45 & 0.32 & 1.09 & 13.7 & 3.11 \\
\hline $\mathrm{Sr}$ & 52,380 & 97,760 & 85,050 & 92,060 & 66,160 & 9236 & 88,520 & 70,167 \\
\hline Mo & 1.5 & 1.87 & 0.48 & 0.73 & 80.5 & 9.82 & 88.6 & 26.2 \\
\hline $\mathrm{Cd}$ & 0.34 & 8.43 & 0.33 & 0.38 & 1.62 & 1.11 & 1.72 & 1.99 \\
\hline In & $<0.05$ & $<0.05$ & $<0.05$ & $<0.05$ & $<0.05$ & $<0.05$ & $<0.05$ & 0.05 \\
\hline Cs & $<0.05$ & $<0.05$ & $<0.05$ & $<0.05$ & $<0.05$ & $<0.05$ & $<0.05$ & 0.05 \\
\hline $\mathrm{Ba}$ & 36,750 & 39,480 & 32,860 & 25,820 & 167,900 & 20,410 & 39,650 & 51,839 \\
\hline $\mathrm{Tl}$ & $<0.05$ & 0.22 & $<0.05$ & $<0.05$ & $<0.05$ & $<0.05$ & $<0.05$ & 0.05 \\
\hline $\mathrm{Pb}$ & 69.7 & 1990 & 109 & 96.4 & 1006 & 944 & 359 & 653 \\
\hline $\mathrm{Bi}$ & 1.69 & 18.6 & 0.23 & 0.07 & 0.71 & 17.2 & 0.9 & 5.63 \\
\hline Th & 2.04 & 5.12 & 2.8 & 1.3 & 6.1 & 16.5 & 24.2 & 8.29 \\
\hline $\mathrm{U}$ & 1.51 & 1.28 & 1.98 & 0.49 & 41.2 & 41 & 2.34 & 12.8 \\
\hline $\mathrm{Nb}$ & 0.54 & 1.08 & 0.54 & 0.56 & 112 & 169 & 3.35 & 41 \\
\hline $\mathrm{Ta}$ & 0.13 & 0.11 & 0.11 & 0.11 & 0.72 & 0.55 & 0.1 & 0.26 \\
\hline $\mathrm{Zr}$ & 0.77 & 0.41 & 0.57 & 0.34 & 18.6 & 144 & 36.9 & 28.8 \\
\hline Hf & 0.44 & 0.36 & 0.39 & 0.38 & 0.63 & 1.87 & 1.21 & 0.75 \\
\hline Sn & 0.35 & 0.54 & 0.41 & 0.32 & 0.6 & 0.96 & 0.38 & 0.51 \\
\hline $\mathrm{Sb}$ & $<0.05$ & $<0.05$ & $<0.05$ & $<0.05$ & 0.08 & 0.14 & $<0.05$ & 0.11 \\
\hline $\mathrm{Ti}$ & 20.3 & 15.1 & 19 & 11.3 & 376 & 2110 & 76.4 & 375 \\
\hline $\mathrm{W}$ & 0.51 & 0.62 & 0.39 & 0.38 & 1.04 & 4.59 & 0.47 & 1.14 \\
\hline As & 6.02 & 3.63 & 4.45 & 3.05 & 12.8 & 2.69 & 27.3 & 8.56 \\
\hline $\mathrm{V}$ & 0.64 & 0.36 & 0.23 & $<0.05$ & 7.17 & 17.6 & 1.09 & 4.52 \\
\hline $\mathrm{La}$ & 15,460 & 13,540 & 14,670 & 11,270 & 26,700 & 7364 & 61,120 & 21,446 \\
\hline $\mathrm{Ce}$ & 18,440 & 16,090 & 17,430 & 14,130 & 30,510 & 9906 & 69,780 & 25,184 \\
\hline $\operatorname{Pr}$ & 1133 & 1113 & 1154 & 1005 & 1893 & 711 & 4623 & 1662 \\
\hline $\mathrm{Nd}$ & 3635 & 3141 & 3370 & 3065 & 4767 & 2215 & 10,140 & 4333 \\
\hline $\mathrm{Sm}$ & 308 & 254 & 270 & 276 & 272 & 207 & 484 & 296 \\
\hline $\mathrm{Eu}$ & 79.7 & 80.1 & 84.1 & 82.6 & 75.3 & 48.3 & 145 & 85 \\
\hline $\mathrm{Gd}$ & 274 & 223 & 243 & 225 & 326 & 207 & 725 & 318 \\
\hline $\mathrm{Tb}$ & 16.7 & 12.2 & 14.4 & 14.4 & 11.7 & 12.8 & 19.6 & 14.5 \\
\hline Dy & 58.6 & 42.8 & 50.3 & 51.5 & 33.6 & 50.2 & 55 & 48.9 \\
\hline Ho & 8.97 & 6.89 & 7.98 & 8.09 & 5.21 & 8.21 & 8.19 & 7.65 \\
\hline $\mathrm{Er}$ & 19.9 & 16.9 & 18.6 & 18.4 & 13.1 & 19.7 & 20.9 & 18.2 \\
\hline $\mathrm{Tm}$ & 2.1 & 1.96 & 2.05 & 2 & 1.49 & 2.31 & 2.22 & 2.02 \\
\hline $\mathrm{Yb}$ & 12.7 & 13.5 & 13.6 & 12.5 & 9.83 & 14.6 & 15.6 & 13.2 \\
\hline $\mathrm{Lu}$ & 1.46 & 1.64 & 1.65 & 1.46 & 1.22 & 1.94 & 1.83 & 1.6 \\
\hline $\mathrm{Sc}$ & 0.47 & 0.43 & 0.48 & 0.32 & 0.67 & 1.84 & 1.21 & 0.77 \\
\hline Y & 146 & 112 & 138 & 121 & 82.1 & 193 & 153 & 135 \\
\hline REE & 39,597 & 34,649 & 37,468 & 30,283 & 64,702 & 20,963 & 147,295 & 53,565 \\
\hline LREE & 39,056 & 34,218 & 36,978 & 29,829 & 64,217 & 20,451 & 146,292 & 53,006 \\
\hline HREE & 541 & 431 & 490 & 455 & 485 & 512 & 1003 & 559 \\
\hline LREE/HREE & 72 & 79 & 75 & 66 & 132 & 40 & 146 & 95 \\
\hline $\mathrm{La}_{\mathrm{N}} / \mathrm{Yb}_{\mathrm{N}}$ & 873 & 719 & 774 & 647 & 1948 & 362 & 2810 & 1162 \\
\hline $\mathrm{Eu} / \mathrm{Eu}^{*}$ & 0.82 & 1.01 & 0.98 & 0.98 & 0.77 & 0.71 & 0.75 & 0.86 \\
\hline $\mathrm{La} / \mathrm{Y}$ & 106 & 121 & 106 & 93 & 325 & 38 & 399 & 159 \\
\hline
\end{tabular}


Bastnäsite is brown, has a variable grain size, and is commonly associated with calcite, strontianitebarite, and quartz. It has $\mathrm{La}_{2} \mathrm{O}_{3}$ and $\mathrm{Ce}_{2} \mathrm{O}_{3}$ contents of 14.3-25.2 and 28.5-39.6 wt. \%, respectively, and a $\mathrm{Y}_{2} \mathrm{O}_{3}$ content of 0.04-19.00 wt. \%. Monazite has $\mathrm{La}_{2} \mathrm{O}_{3}$ and $\mathrm{Ce}_{2} \mathrm{O}_{3}$ contents of 12.99-13.36 and 37.8-38.8 wt. \%, respectively. Apatite has $\mathrm{La}_{2} \mathrm{O}_{3}$ and $\mathrm{Ce}_{2} \mathrm{O}_{3}$ contents of $0.26-0.94$ and 2.02-3.96 wt. \%, respectively, and contains 25.6-33.2 wt. \% $\mathrm{SiO}_{2}$ and up to $40 \mathrm{wt}$. \% CaO. Ca-strontianite has lower $\mathrm{La}_{2} \mathrm{O}_{3}\left(0.00-7.48\right.$ wt. \%) and $\mathrm{Ce}_{2} \mathrm{O}_{3}\left(0.19-15.9\right.$ wt. \%) contents than those of parisite (with $\mathrm{La}_{2} \mathrm{O}_{3}$ and $\mathrm{Ce}_{2} \mathrm{O}_{3}$ contents of 12.6-14.3 and 30.2-34.8 wt. \%, respectively) or bastnäsite, and $\mathrm{CaO}$ and SrO contents of 9.2-16.2 and 24.2-59.7 wt. \%, respectively. Ancylite has $\mathrm{La}_{2} \mathrm{O}_{3}, \mathrm{Ce}_{2} \mathrm{O}_{3}$, and $\mathrm{CaO}$ contents of 12.5-13.7, 29.3-30.9, and 0.35-0.58 wt. \%, respectively (Table 4). In these samples, the gangue minerals are mainly calcite, barite, quartz, muscovite, dolomite, pyrite, sphalerite, galena, chalcopyrite, K-feldspar, and albite. Accessory minerals include rutile and titanite. Sulfides are widely distributed in the ores, and include pyrite, galena, pyrrhotite, chalcopyrite, and molybdenum sulfide (Table 5).

\subsection{In Situ LA-ICP-MS Analyses}

Chondrite-normalized REE patterns of individual REE-bearing and gangue minerals are shown in Figure 7. Barite has low $\Sigma$ REE contents of 103-217 ppm (mean $=156 \mathrm{ppm})$ and high $(\mathrm{La} / \mathrm{Yb})_{\mathrm{N}}$ ratios of 1655-3552 $($ mean $=2670)($ Figure 7a). Calcite has the most variable $\Sigma$ REE contents of 146-13,120 ppm $($ mean $=1832 \mathrm{ppm}),(\mathrm{La} / \mathrm{Yb})_{\mathrm{N}}$ ratios of $0.5-178$, and chondrite-normalized REE patterns exhibiting negative slopes with no Eu anomalies (Table 6 and Figure $7 \mathrm{~b}$ ).
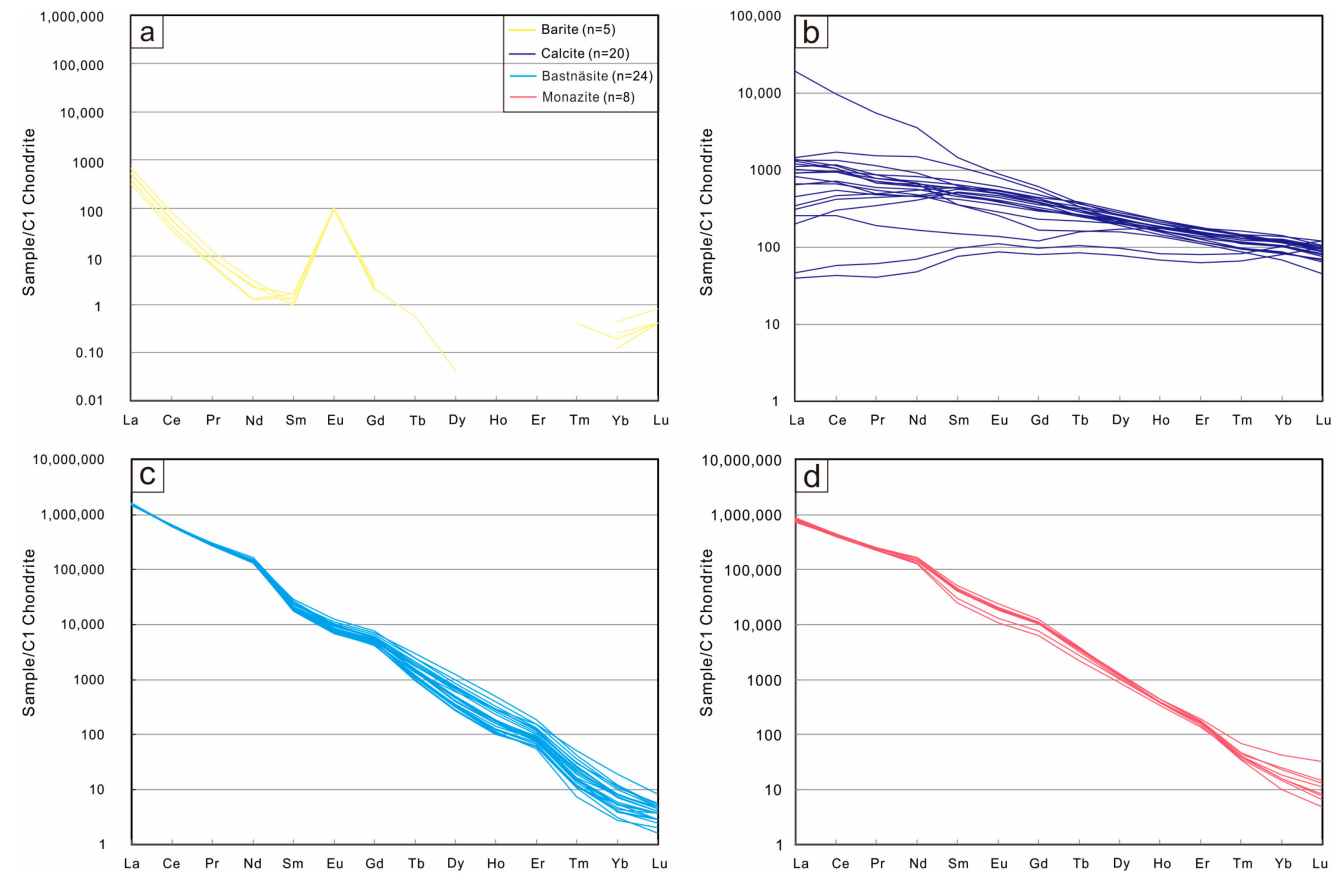

Figure 7. Chondrite-normalized REE patterns for (a) barite, (b) calcite, (c) bastnäsite, and (d) monazite in disseminated ores. Normalizing values are after [57].

Bastnäsite has the highest $\Sigma$ REE content of 834,229-843,089 ppm (mean $=840,349$ ppm), with $(\mathrm{La} / \mathrm{Yb})_{\mathrm{N}}$ ratios of 89,248-610,829 (mean $\left.=279,094\right)$ (Figure 7c). Monazite has $\Sigma \mathrm{REE}$ contents of $515,791-575,998$ ppm $($ mean $=551,583 \mathrm{ppm})$, with $(\mathrm{La} / \mathrm{Yb})_{\mathrm{N}}$ ratios of 19,215-93,809 $($ mean $=49,549)$ (Figure 7f). Parisite has low $\Sigma R E E$ contents of 43-136 ppm (mean $=97 \mathrm{ppm})$, with $(\mathrm{La} / \mathrm{Yb})_{\mathrm{N}}$ ratios of 2.32-7.23 (mean = 4.71) (Table 6). Bastnäsite and monazite, rather than paristite, are the main REE-bearing minerals in the Weishan REE deposit. 


\subsection{Whole-Rock Geochemical Analyses}

Major and trace element compositions of disseminated ores in veinlets are reported in Table 7. The analyzed Weishan $\mathrm{REE}$ ores have $\mathrm{SiO}_{2}$ and $\left(\mathrm{Na}_{2} \mathrm{O}+\mathrm{K}_{2} \mathrm{O}\right)$ contents of 0.37-13.68 and 0.07-0.95 wt. \%, respectively, with $\mathrm{MgO}, \mathrm{CaO}$, and $\mathrm{Fe}_{2} \mathrm{O}_{3}$ contents of 0.06-0.86, 22.57-41.05, and 0.10-7.49 wt. \%, respectively. The Weishan REE ores are characterized by low $\mathrm{Cr}$ and high large-ion lithophile element (LILE) contents, with Sr and Ba contents of 9236-97,760 and 20,410-167,900 ppm, respectively. These ores are enriched in LREEs ( $\Sigma$ LREE $=20,451-146,292 \mathrm{ppm})$ and HREEs ( $\Sigma$ HREE $=431-1003$ ppm), and exhibit Eu anomalies (Figure 8). Strong fractionation of LREE over HREE is evident.
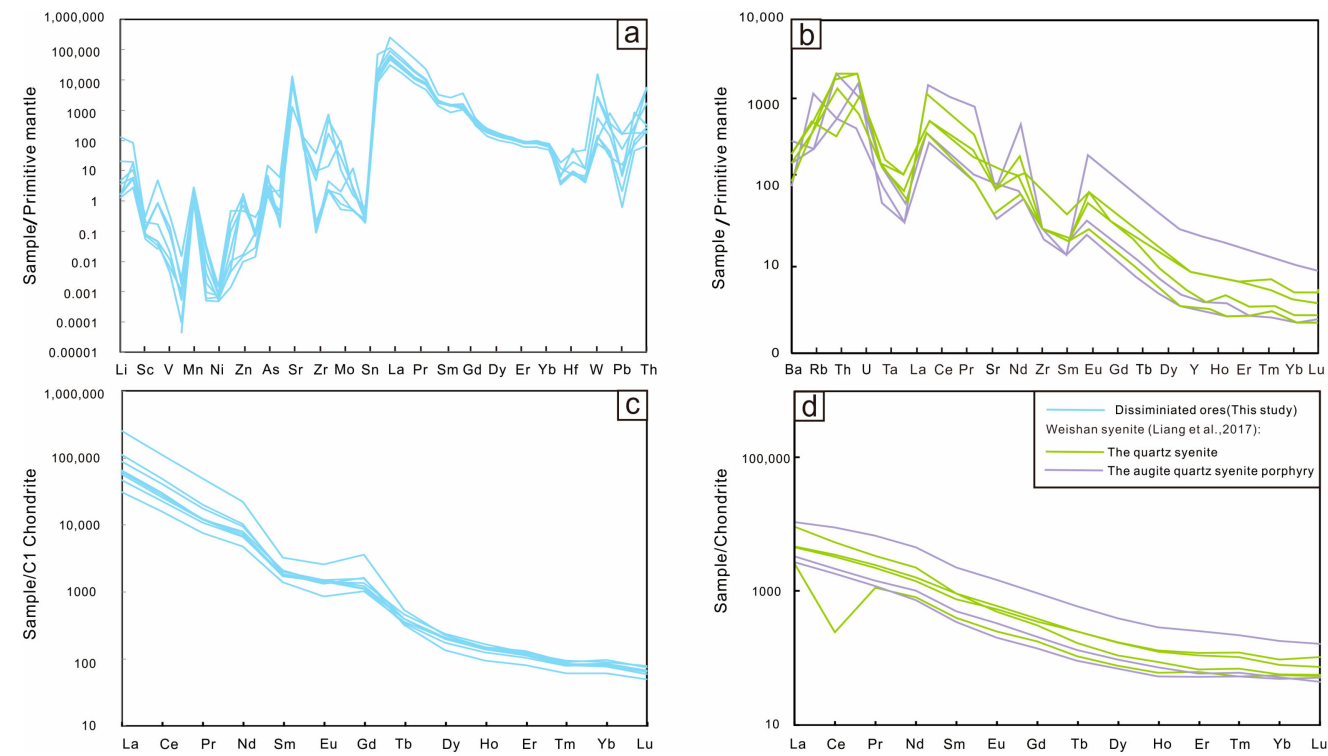

Figure 8. (a,b) Primitive-mantle-normalized trace element diagrams and (c,d) chondrite-normalized REE patterns of REE ores and syenites from the Weishan REE deposit. (b,d from [50]; normalizing values are after [57]).

\section{Discussion}

\subsection{Mineralized Carbonatite in the Weishan Deposit}

Carbonatite-related REE deposits with high REE grades are favored targets for exploration [7,12,58-62]. Mineralized carbonatites that host REE deposits commonly have high REE, Ba, and Sr contents, but their fertility is not correlated with $\mathrm{CaO} / \mathrm{MgO}$ or $\mathrm{FeO} / \mathrm{MgO}$ ratios (Figure 9). Ore contents of REE, $\mathrm{Ba}$, and $\mathrm{Sr}$ in the Weishan deposit are higher than those of large REE deposits elsewhere, with Weishan data plotting in the mineralized field in REE-(CaO/MgO), REE-(FeO/MgO), REE-Ba, and REE-(Sr/Ba) diagrams (Figure 9). The higher REE contents than those of Bayan Obo and Maoniuping carbonatites suggest that the Weishan carbonatite-syenite complex has the potential to host large or giant REE deposits, with mineralized carbonatites hosting REE deposits with both high and low REE grades.

Although the Weishan REE deposit has various types of wall rock (including gneiss), the main REE-bearing material is considered as originating directly from the carbonatite-syenite complex. Liang and Ying [50,63] studied the syenite and carbonatite separately. Weishan quartz syenite and aegirine-quartz syenite are characterized by high alkali contents, metaluminous composition, and relatively low $\mathrm{Ti}, \mathrm{Fe}, \mathrm{Mg}$, and $\mathrm{Mn}$ contents, with alkaline affinities. There is strong fractionation of LREE and HREE, with REE patterns displaying enrichment in LREE and depletion in HREE, with small positive and negative $\mathrm{Eu}$ anomalies $\left(\mathrm{Eu} / \mathrm{Eu}^{*}=0.90-1.05\right)$. The ores are rich in LILEs such as $\mathrm{Rb}$ and other elements such as Th and $U$ and depleted in high-field-strength elements (HFSEs), such as $\mathrm{Nb}, \mathrm{Ta}, \mathrm{Zr}$, and Hf (Figure $8 \mathrm{~b}, \mathrm{~d}$ ). 

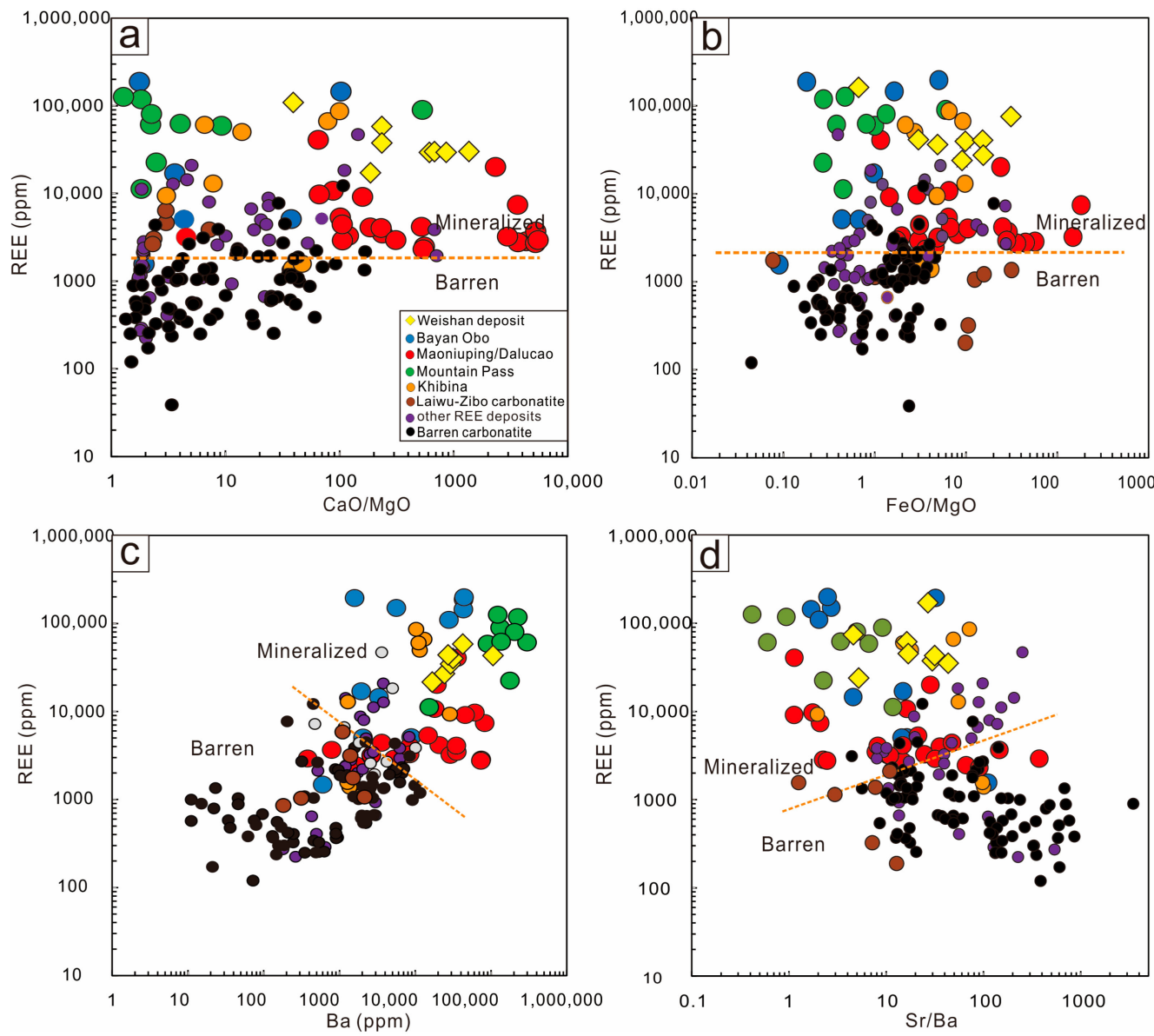

Figure 9. (a) REE- $(\mathrm{CaO} / \mathrm{MgO})$ and (b) $\mathrm{REE}-(\mathrm{FeO} / \mathrm{MgO})$ diagrams for examples of carbonatites. These data indicate that REE enrichment is unrelated to the type of carbonatite and its major element composition (most data are from Table 4 in [12,63]). (c) REE-Ba and (d) REE-(Sr/Ba) diagrams for the Weishan deposit and other examples of mineralized and barren carbonatites. Carbonatites associated with giant CARDs have extremely high $\mathrm{Ba}$ and REE contents, positive Ba-REE correlations, and negative (Sr/Ba)-REE correlations (data from [12,63]).

Fresh carbonatite in the Weishan REE deposit has not yet been studied, although the Laiwu-Zibo carbonatites (LZCs) from around the Weishan deposit have been studied [63]. The LZCs have high $\mathrm{Sr}$ (up to $5000 \mathrm{ppm}$ ) and Nd (up to $2000 \mathrm{ppm}$ ) contents. Their REE patterns show strong enrichment in LREEs with small negative Eu anomalies. Their primitive-mantle-normalized diagrams exhibit enrichment in Ba (574-18,072 ppm), Th (15.4-170 ppm), Sr (927-5366 ppm), U (2.07-22.1 ppm), LREE (1084-9695 ppm), HREE (46-247 ppm), and $\Sigma$ REE (1130-9942 ppm), and marked depletion in Rb (4.6-231 ppm), Zr (30-596 ppm), and Hf (0.61-13.6 ppm) [63].

The Weishan REE ores are characterized by low $\mathrm{Cr}$ contents and $\mathrm{Zr}$ and $\mathrm{Hf}$ anomalies, with enrichment in LILEs and HFSEs. They are enriched in LREEs (20,451-146,292 ppm) and depleted in HREEs (431-1003 ppm). Considering that the carbonatite-syenite complex and REE ores have similar REE patterns and trace element compositions, it is concluded that the carbonatite-syenite complex is the main contributor of disseminated REE ores, or that it crystallized in equilibrium with other types of ore. The Weishan REE ores also have high Sr (9235-97,760 ppm) and Ba (25,820-167,900 ppm) contents, consistent with other REE mineralized carbonatites [11,12].

Magmatic and hydrothermal stages have been recognized in this and previous studies. Typical disseminated REE ore samples from the Weishan deposit commonly contain bastnäsite (Figure $5 \mathrm{a}, \mathrm{b}, \mathrm{d}, \mathrm{f}$ ), parisite (Figure $5 \mathrm{a}, \mathrm{b}, \mathrm{f}, \mathrm{i}$ ), monazite (Figure $5 \mathrm{c}-\mathrm{e}$ ), REE-bearing apatite (Figure $5 \mathrm{~g}$ ), and Ca-strontianite (Figure $5 \mathrm{~g}, \mathrm{~h}$ ). The main gangue minerals are calcite, barite, quartz, phlogopite, fluorite, dolomite, 
K-feldspar, albite, and rutile. Quartz, barite, calcite, and other gangue minerals were overprinted by or formed in equilibrium with bastnäsite, parisite, monazite, and other REE minerals (Figure 5), indicating that these REE minerals formed at a relatively late stage, coeval with other gangue minerals.

Bastnäsite is the most important economic mineral in the deposit and occurs in a wide variety of mineral assemblages, with crystal lengths of 20-200 $\mu \mathrm{m}$. Bastnäsite and parisite crystallized in equilibrium with calcite. Euhedral bastnäsite crystals formed coevally with parasite, and barite formed in a subsequent phase or in equilibrium with bastnäsite and parisite (Figure 5a). Parisite crystals have lengths of 10-100 $\mu \mathrm{m}$, with most being in equilibrium with calcite, barite, and bastnäsite (Figure $5 \mathrm{~b}$ ). In general, parisite contains less amount than bastnäsite. Monazite occurs mainly as isolated elongate grains that are $50-150 \mu \mathrm{m}$ diameter, with some being massive or occurring as columnar aggregates (Figure 5c). Biotite, quartz, calcite, phlogopite, and calcite were overprinted by or formed in equilibrium with monazite and celestite. K-feldspar and albite in ores occur as relicts overprinted by monazite.

Gangue minerals in the deposit include apatite, Ca-strontianite, calcite, quartz, barite, phlogopite, K-feldspar, albite and dolomite (Table 5; Figure 5). Apatite crystals (20-50 $\mu \mathrm{m}$ length) are euhedral and elongate and occur as aggregates with calcite and as overgrowths on other gangue minerals. Apatite coexists with Ca-strontianite, which is scarce, fractured, and occurs as overgrowths on calcite and other gangue minerals (Figure 5g). Ca-strontianite also occurs with other minerals, with lower $\mathrm{La}_{2} \mathrm{O}_{3}$ and $\mathrm{Ce}_{2} \mathrm{O}_{3}$ contents than those of parisite or bastnäsite and high $\mathrm{CaO}$ and $\mathrm{SrO}$ contents of 9.2-16.2 and 24.2-59.7 wt. \%, respectively (Figure $5 \mathrm{~h}$ ).

Calcite is the most common ganue mineral, accounting for at least $30 \%$ of REE ores. It is translucent and white or pale pink and commonly occurs with euhedral bastnäsite. We infer that calcite formed after other minerals, such as barite and parasite, because it overgrows these minerals (Figure 5a,b,f). Barite $(0.2-1.5 \mathrm{~mm}$ ) is hypidiomorphic to euhedral and occurs with bastnäsite (Figure 5a,b,d,f). Quartz is common in all types of ore and occurs as hypidiomorphic, xenomorphic, and granular grains (Figure $5 \mathrm{~d}-\mathrm{g}$ ).

K-feldspar and albite occur in some ores, mainly as relict grains (Figure 5c), indicating that gneiss, syenite, and other wall rocks underwent alteration. Petrographic studies and ore occurrences indicate that REE mineralization occurred through alteration of syenite or gneiss or other wall rocks, mainly in the later hydrothermal stage.

Sphalerite is the most widely distributed sulfide mineral, was generally formed in the later hydrothermal stage, and in most cases is associated with galena. It is irregular in shape and 200-900 $\mu \mathrm{m}$ in diameter. Galena occurs along sphalerite grain boundaries and phlogopite occurs within sphalerite-galena intergrowths (Figure 5g). Pyrite is often associated with other sulfide minerals and formed during late-stage hydrothermal alteration. Idiomorphic pyrite $(200-800 \mu \mathrm{m})$ is intergrown with phlogopite and occurs with quartz and galena (Figure 5i). Petrographic studies indicate that pyrite and other sulfides may have precipitated after the gangue minerals.

Based on petrographic studies and the geological setting, REE mineralization occurred through the magmatic to hydrothermal stages. During the magmatic stage, quartz, zircon, apatite, K-feldspar, albite, arfvedsonite, aegirine, and magnetite formed in the syenite-carbonatite complex. In the hydrothermal stage, barite, calcite, quartz, muscovite, strontianite, titanite, and thorite formed as the main gangue minerals. REE minerals such as britholite, parisite, and bastnäsite formed during late-stage hydrothermal alteration. These minerals were overgrown by sphalerite, pyrite, and galena. Based on previous studies [15], the general sequence of mineral formation is shown in Figure 6, which indicates that all carbonatite-syenite-related REE deposits have similar formation processes. The magmatic, hydrothermal, and sulfide stages can be separated on the basis of the results of this study, and those of the Maoniuping, Dalucao, Lizhuang, and Muluozhai REE deposits [13,29,35]. For the magmatic stage, the deposits have mineral compositions similar to those of a carbonatite-syenite complex. During the later hydrothermal stage, gangue minerals such as fluorite, barite, calcite, quartz, muscovite, strontianite, titanite, thorite, arfvedsonite, and aegirine-augite formed. Due to the high degree of alteration, arfvedsonite and aegirine-augite are found only in the Maoniuping and Bayan 
Obo REE deposits $[29,30,64]$. The occurrence of arfvedsonite and aegirine-augite in the Weishan ores thus suggests a high degree of alteration in carbonatite-related REE deposits.

\subsection{Comparison of Ore Types and REE Mineralization Stages}

Single veins and veinlets occur in orebodies of the Weishan REE deposit [49]. Single veins clearly cut the wall rock and are continuous, regular, and relatively thick. Veinlets occur around single veins. Single veins are 30-540 $\mathrm{m}$ long and 0.1-9.2 $\mathrm{m}$ wide. Veinlets are short and thin. Isolated veinlets have little economic significance, unlike closely spaced veinlets [51]. Disseminated ores occur mainly in Neoarchean gneiss and Early Cretaceous intrusive rocks as veinlets [49]. In terms of mineral assemblages, ore veins comprise mainly quartz, fluorite, barite, celestite, calcite, REE minerals, and sulfate; veins containing REE minerals occur in aegirine-augite-altered granitic porphyry. Ore veins containing quartz, fluorite, sulfate, calcite, sulfides, and britholite formed principally during hydrothermal alteration. In these types of ore vein, the gangue minerals are quartz, fluorite, calcite, barite, pyrite, galena, chalcopyrite, muscovite, and K-feldspar, and the REE minerals are mainly bastnäsite, parisite, monazite, thorite, uranium-rich pyrochlore, britholite, and ancylite. Fluorite, calcite, and sulfides are coarse-grained [65].

Hand-specimen examination, BSE images, and previous studies [14] indicate two main stages: a carbonatite-syenite complex stage, and a hydrothermal stage (Figure 6). Relict K-feldspar, quartz, and other minerals in ores suggest the existence of a carbonatite-syenite complex stage, with barite, celestite, and aegirine-augite minerals forming in the hydrothermal stage.

Based on the relative timing of the veins and stages of mineralization, barite and fluorite commonly formed earlier than or in equilibrium with REE minerals, which supports the interpretation that both minerals may be important for REE mineral formation. This could explain why, in disseminated ores, less fluorite and barite occur together with minor bastnäsite ( $0.4 \%$ to $2.9 \%)$. Similar carbonatite-related REE ores occur along the Mianning-Dechang REE belt, such as weathered and brecciated ores of the Dalucao deposit, ore veins of the Maoniuping deposit, and disseminated ores of the Lizhuang deposit (Table 1) [13,29]. REE ores in veins including barite, fluorite, calcite, and bastnäsite commonly have high REE grades of $>10 \%$, whereas individual barite, fluorite, calcite, and bastnäsite grades may be $<2 \%$, further indicating the importance of fluoride and sulfate in REE mineral formation (Table 1).

\subsection{Magmatic-Hydrothermal REE Enrichment}

Two factors are required to form CARDs: REE enrichment of the mantle by subduction processes [12], and liberation and enrichment of REEs during magmatism and hydrothermal alteration. The carbonatite-syenite complex at Weishan appears to be mineralized, based on its REE content being similar to those of the Mianning-Dechang REE belt and Laiwu-Zibo carbonatites $[12,63,66]$. Furthermore, the Weishan complex has been regarded as the host rock for the REE deposits. The enrichment of REEs during hydrothermal alteration is also important, and some mineralized carbonatite-syenite complexes have limited grades. The occurrence of disseminated ores may explain the low grades in veinlets of such deposits. Based on petrographic studies of disseminated ores and mineral assemblages in various types of ore, it is likely that several factors cause the low grades.

Many studies have focused on factors controlling the transport and precipitation of REEs, which can be transported in a diverse range of high-temperature fluid systems that are rich in sulfate, carbonate, fluoride, chloride, and hydroxyl ions $[60,67]$. Experimental studies have shown that sulfate ions can form stable complexes with REEs and could be important for REE transport $[58,68]$. Sulfate complexes are particularly important for REE transport under high-temperature and mildly acidic to near-neutral $\mathrm{pH}$ conditions [69]. However, in disseminated ores, the low barite content indicates that sulfate ion and REE activity is very low in the ore-forming fluids. Carbonate ions are also thought to form strong complexes with REEs [68,70,71], and REE enrichment shows a positive correlation with $\mathrm{CO}_{2}$ activity in some hydrothermal REE deposits such as the Bayan Obo and Maoniuping deposits in China, the Wicheeda deposit in Canada, and the Sin Quyen deposit in NW Vietnam [2,13,67,72]. 
Hydrothermal carbonate minerals such as calcite occur in ores in the Weishan deposit, indicating high $\mathrm{CO}_{2}$ activity in the ore-forming fluids. Among the ligands mentioned above, REEs form their strongest complexes with fluoride ions [58,68,71]. Furthermore, in many carbonatite-related hydrothermal REE deposits, F-rich hydrothermal minerals, such as fluorite, fluorapatite, and other F-bearing minerals, indicate abundant fluoride in the ore-forming fluids $[7,9,73]$. In the disseminated ores of the Weishan deposit, only fluorapatite and phlogopite contain detectable F (but at low concentrations), indicating that the ore-forming fluids had low $\mathrm{F}^{-}$concentrations. Moreover, fluorite and REE fluorocarbonates are rare, despite the high REE and Ca activities of the ore-forming fluids. This indicates that although $\mathrm{F}^{-}$was present in the fluids, its activity was relatively low, resulting in reduced REE transport in the disseminated ores of the Weishan deposit.

Mineralized carbonatites that host REE deposits commonly have high REE, Ba, and Sr contents [12]. Concentrations of REEs, $\mathrm{Ba}$, and $\mathrm{Sr}$ at Weishan are higher than those of giant or large REE deposits elsewhere in the world, with data for Weishan plotting in the mineralized field in $\mathrm{REE}-(\mathrm{CaO} / \mathrm{MgO})$, $\mathrm{REE}-(\mathrm{FeO} / \mathrm{MgO}), \mathrm{REE}-\mathrm{Ba}$, and REE-(Sr/Ba) diagrams $[12,13]$. The high REE contents suggest that the carbonatite-syenite complex at Weishan has the potential to host large or giant REE deposits.

In the ore area, four groups of fractures controlled ore formation, with NW-SE- and NE-SW-trending fractures being associated with REE mineralization [15]. During early stages of mineralization, local tectonic activity produced fractures or fissures in carbonatite-syenite complexes, facilitating fluid cycling and the modification of fluid chemistry by water-rock interactions. Circulation of ore fluids in fractures drove alteration within the carbonatite and led to high concentrations of $\mathrm{REEs}^{-} \mathrm{F}^{-}, \mathrm{Cl}^{-}$, $\mathrm{CO}_{2}, \mathrm{SO}_{4}{ }^{2-}$, and volatiles in the fluids. Deposits within the Mianning-Dechang REE belt indicate structural controls and exhibit a range of ore types associated with fluid infiltration, such as brecciated ores and ore veins. In contrast, in the Lizhuang deposits, where weaker tectonic activity is recorded, only disseminated ores have been found. Weak tectonic activity thus inhibits hydrothermal alteration and restricts large-scale REE mineralization. Tectonic activity also drives the infiltration of meteoric water, which reduces temperature, thereby facilitating the precipitation of REE-bearing minerals $[60,74]$. The occurrence and mineral assemblages of the ore veins and veinlets indicate that disseminated ores in veinlets experienced less tectonic activity, which would have hindered the circulation of hydrothermal fluids (Figure 3c,d).

Certain ligands in solution are necessary for REE transport or precipitation, and mechanisms of REE enrichment by transportation and precipitation are a major focus of current research into REE deposits. Laboratory experiments, theoretical studies, and analyses of natural examples suggest that REEs can be transported in a diverse range of high-temperature fluid systems that are rich in sulfate, carbonate, fluoride, chloride, and hydroxyl ions [32,33,60,75]. Sulfate and fluoride ions form stable complexes with REEs and could be important for REE transport and precipitation, respectively [60]. Carbonate ions are also known to form strong complexes with REEs [58,71], and the positive correlation between REE enrichment and $\mathrm{CO}_{2}$ activity has been well established in hydrothermal carbonatite-related deposits such as at Bayan Obo and Maoniuping in China, the Wicheeda deposit in Canada, and the Sin Quyen deposit in NW Vietnam [2,13,67,72]. Moreover, REE sulfate and carbonate complexes are particularly important in high-temperature and mildly acidic to near-neutral pH conditions $[60,69,76]$. Large and giant REE deposits generally contain large amounts of fluorine- and sulfate-bearing minerals such as fluorite, fluorapatite, barite, and celestite as the main gangue minerals. The abundance of these minerals implies high fluoride and sulfate contents in the ore-forming fluids [7,13]. However, fluorite and barite are rare in disseminated ores (Table 5), suggesting that fluorine and sulfate contents were low in the ore-forming fluids, with a consequent reduction in transport and precipitation of REEs. We conclude that low concentrations of suitable ligands for REEs is another factor that inhibited REE mineralization at Weishan. 


\section{Conclusions}

(1) Based on petrographic studies of disseminated ores in the veinlets in the Weishan deposit, REE mineral formation is inferred to have occurred during the late stage of hydrothermal evolution, as REE minerals occur in equilibrium with or formed after gangue minerals such as barite, calcite, and quartz, which were overprinted by REE minerals.

(2) Petrographic, XRD, and geochemical data indicate that the disseminated ores have lower grades, with less barite and fluorite than the vein and veinlet ores in the same deposit. In contrast, ore veins with high grades have high barite, fluorite, calcite, and bastnäsite contents.

(3) Several factors controlled the low grades of the disseminated ores in the veinlets. Relatively limited tectonic activity reduced the circulation of fluids, and $\mathrm{F}^{-}$and $\mathrm{SO}_{4}{ }^{2-}$, which facilitated the transport and precipitation of REE, were present in only minor amounts in the ore-forming fluids. Our examination of the massive ores explains not only the reasons for their low grades but also the reasons for their differences from other REE deposits.

Author Contributions: Y.-h.J. and Y.L. undertook the field work; Y.-h.J. performed the experiments; Y.-h.J. and Y.L. analyzed the data; Y.-h.J. wrote the paper; Y.L. revised the paper. All authors have read and agreed to the published version of the manuscript.

Funding: This research was funded by the Strategic Priority Research Program of the Chinese Academy of Sciences (Grant No. XDA20070304), National Science Fund for Excellent Young Scholars (41922014), National Natural Science Foundation of China (Grant No. 41702096, 41772044), Fundamental Research Funds for the Chinese Academy of Geological Sciences (Grant No. YYWF201705), and Geological Survey Program of the China Geological Survey, Ministry of Natural Resources (Grant No. DD20190060), Key Special Project for Introduced Talents Team of Southern Marine Science and Engineering Guangdong Laboratory (Guangzhou) (GML2019ZD0106).

Acknowledgments: We thank Jian-kang Li at the Institute of Mineral Resources, Chinese Academy of Geological Sciences, Hai-dong Zhang at the school of earth science and resources, Chang'an Univeristy, and three anonymous reviewers for excellent comments and suggestions for this paper.

Conflicts of Interest: The authors declare no conflict of interest.

\section{References}

1. Bell, K.; Tillton, G.R. Nd, Pb and $\mathrm{Sr}$ isotopic compositions of East Africa carbonatites: Evidence for mantle mixing and plume inhomogeneity. J. Petrol. 2001, 42, 1927-1945. [CrossRef]

2. Smith, M.P.; Henderson, P. Preliminary fluid inclusion constraints on fluid evolution in the Bayan Obo Fe-REE-Nb deposit, Inner Mongolia, China. Econ. Geol. 2000, 95, 1371-1388. [CrossRef]

3. Castor, S.B. The Mountian Pass rare-earth carbonatite and associated ultrapotassic rocks, California. Can. Miner. 2008, 46, 779-806. [CrossRef]

4. Samson, I.M.; Liu, W.; Williams-Jones, A.E. The nature of orthomagmatic hydrothermal fluids in the Oka carbonatite, Quebec, Canada: Evidence from fluid inclusions. Geochim. Cosmochim. Acta 1995, 59, 1963-1977. [CrossRef]

5. Van Gosen, B.S.; Verplanck, P.L.; Emsbo, P. Rare Earth Element Mineral Deposits in the United States; US Geological Survey: Reston, VA, USA, 2019; Volume 1454, p. 16.

6. Chakhmouradian, A.R.; Wall, F. Rare earth elements: Minerals, mines, magnets (and more). Elements 2012, 8, 333-340. [CrossRef]

7. Kynicky, J.; Smith, M.P.; Xu, C. Diversity of rare earth deposits: The key example of China. Elements 2012, 8, 361-367. [CrossRef]

8. Veksler, I.V.; Petibon, C.; Jenner, G.A.; Dorfman, A.M.; Dingwell, D.B. Trace element partitioning in immiscible silicatecarbonate liquid systems: An initial experimental study using a centrifuge autoclave. J. Petrol. 1998, 39, 2095-2104. [CrossRef]

9. Yang, X.Y.; Sun, W.D.; Zhang, Y.X.; Zheng, Y.F. Geochemical constraints on the genesis of the Bayan Obo $\mathrm{Fe}-\mathrm{Nb}-\mathrm{REE}$ deposit in inner Mongolia, China. Geochim. Cosmochim. Acta 2009, 73, 1417-1435. [CrossRef]

10. Smith, M.P.; Moore, K.; Kavecsánszki, D.; Finch, A.A.; Kynicky, J.; Wall, F. From mantle to critical zone: A review of large and giant sized deposits of the rare earth elements. Geosci. Front. 2016, 7, 315-334. [CrossRef] 
11. Hou, Z.Q.; Tian, S.H.; Xie, Y.L.; Yang, Z.S.; Yuan, Z.X.; Yin, S.P.; Yi, L.S.; Fei, H.C.; Zou, T.R.; Bai, G.; et al. The Himalayan Mianning-Dechang REE belt associated with carbonatite-alkaline complexes, eastern Indo-Asian collision zone, SW China. Ore Geol. Rev. 2009, 36, 65-89. [CrossRef]

12. Hou, Z.Q.; Liu, Y.; Tian, S.H.; Yang, Z.M.; Xie, Y.L. Formation of carbonatite-related giant rare-earth-element deposits by the recycling of marine sediments. Sci. Rep. 2015, 5, 10231. [CrossRef] [PubMed]

13. Liu, Y.; Hou, Z.Q. A synthesis of mineralization styles with an integrated genetic model of carbonatite-syenitehosted REE deposits in the Cenozoic Mianning-Dechang REE metallogenic belt, the eastern Tibetan Plateau, southwestern China. J. Asian Earth Sci. 2017, 137, 35-79. [CrossRef]

14. Lan, T.G.; Fan, H.R.; Hu, F.F.; Yang, K.F.; Wang, Y. Genesis of the Weishan REE deposit, Shandong Province: Evidences from $\mathrm{Rb}$-Sr isochron age, LA-MC-ICPMS Nd isotopic compositions and fluid inclusions. Geochimica 2011, 40, 428-438. (In Chinese with English abstract)

15. Wang, J.F.; Sun, M.T.; Du, X.B.; Gan, Y.J.; Zhang, G.Q.; Wang, Z.L. Geological Characteristics and Prospecting Potentiality of Xishan Rare Earth Deposit in Shandong Province. Shandong Land Resour. 2016, 32, 32-40. (In Chinese with English abstract)

16. Lottermoser, B.G. Rare-earth element mineralization within the Mt. Weld carbonatite laterite, Western Australia. Lithos 1990, 24, 151-167. [CrossRef]

17. Mariano, A.N. Nature of Economic Mineralization in Carbonatites and Related Rocks. In Carbonatites: Genesis and Evolution; Unwin: London, UK, 1989.

18. De Toledo, M.C.M.; de Oliveira, S.M.B.; Fontan, F.; Ferrari, V.C.; de Parseval, P. Mineralogia, morfologia e cristaloquímica da monazita de Catalão I (GO, Brasil). Rev. Bras. de Geociências 2004, 34, 135-146. [CrossRef]

19. Lazareva, E.V.; Zhmodik, S.M.; Dobretsov, N.L. Main minerals of abnormally high-grade ores of the Tomtor deposit (Arctic Siberia). Russ. Geol. Geophys. 2015, 56, 844-873. [CrossRef]

20. Castor, S.B.; Hedrick, J.B. Rare earth elements. In Industrial Minerals Volume, 7th ed.; Society for Mining, Metallurgy and Exploration Littleton: Englewood, IL, USA, 2006; pp. 769-792.

21. Mariano, A.N.; Mariano, A. Rare earth mining and exploration in North America. Elements 2012, 8, 369-376. [CrossRef]

22. Bell, K.; Blenkinsop, J. Nd and Sr isotopic composition of East African carbonatites: Implications for mantle heterogeneity. Geology 1987, 15, 99-102. [CrossRef]

23. Bell, K.; Simonett, A. Erratum to: Source of parental melts to carbonatites-Critical isotopic constraints. Miner. Petrol. 2010, 98, 77-89. [CrossRef]

24. Ye, H.M.; Li, X.H.; Lan, Z.W. Geochemical and Sr-Nd-Hf-O-C isotopic constraints on the origin of the Neoproterozoic Qieganbulake ultramafic-carbonatite complex from the Tarim Block, Northwest China. Lithos 2013, 182, 150-164. [CrossRef]

25. Xu, C.; Kynicky, J.; Chakhmouradian, A.R.; Campbell, I.H.; Allen, C.M. Trace-element modeling of the magmatic evolution of rare-earth-rich carbonatite from the Miaoya deposit, Central China. Lithos 2010, 118, 145-155. [CrossRef]

26. Xu, C.; Kynicky, J.; Chakhmouradian, A.R.; Li, X.; Song, W. A case example of the importance of multi-analytical approach in deciphering carbonatite petrogenesis in South Qinling orogen: Miaoya rare-metal deposit, central China. Lithos 2015, 227, 107-121. [CrossRef]

27. Turlin, F.; André-Mayer, A.S.; Moukhsil, A.; Vanderhaeghe, O.; Gervais, F.; Solgadi, F.; Groulier, P.A.; Poujol, M. Unusual LREE-rich, peraluminous, monazite- or allanite-bearing pegmatitic granite in the central Grenville Province, Québec. Ore Geol. Rev. 2017, 89, 627-667. [CrossRef]

28. Turlin, F.; Vanderhaeghe, O.; Gervais, F.; André-Mayer, A.S.; Moukhsil, A.; Zeh, A.; Solgadi, F.; I.P.T.N. Petrogenesis of LREE-rich pegmatitic granite dykes in the central Grenville Province by partial melting of Paleoproterozoic-Archean metasedimentary rocks: Evidence from zircon U-Pb-Hf-O isotope and trace element analyses. Precambrian Res. 2019, 327, 327-360. [CrossRef]

29. Liu, Y.; Chakhmouradian, A.R.; Hou, Z.Q.; Song, W.L.; Kynický, J. Development of REE mineralization in the giant Maoniuping deposit (Sichuan, China): Insights from mineralogy, fluid inclusions, and trace-element geochemistry. Miner. Deposita 2019, 54, 701-718. [CrossRef]

30. Liu, Y.; Hou, Z.Q.; Zhang, R.Q.; Wang, P.; Gao, J.F.; Raschke, M.B. Zircon Alteration as a Proxy for Rare Earth Element Mineralization Processes in Carbonatite-Nordmarkite Complexes of the Mianning-Dechang Rare Earth Element Belt, China. Econ. Geol. 2019, 114, 719-744. [CrossRef] 
31. Guo, D.X.; Liu, Y. Occurrence and geochemistry of bastnäsite in carbonatite-related REE deposits, Mianning-Dechang REE belt, Sichuan Province, SW China. Ore Geol. Rev. 2019, 107, 266-282. [CrossRef]

32. Shu, X.C.; Liu, Y. Fluid inclusion constraints on the hydrothermal evolution of the Dalucao Carbonatite-related REE deposit, Sichuan Province, China. Ore Geol. Rev. 2019, 107, 41-57. [CrossRef]

33. Zheng, X.; Liu, Y. Mechanisms of element precipitation in carbonatite-related rare-earth element deposits: Evidence from fluid inclusions in the Maoniuping deposit, Sichuan Province, southwestern China. Ore Geol. Rev. 2019, 107, 218-238. [CrossRef]

34. Yuan, Z.X.; Shi, Z.M.; Bai, G.; Wu, C.Y.; Chi, R.A.; Li, X.Y. The Maoniuping Rare Earth Ore Deposit, Mianning County, Sichuan Province; Seismological Publishing House: Beijing, China, 1995; pp. 5-70. (In Chinese)

35. Yang, Z.X.; Williams-Jones, A.E.; Pu, G.P. Geological features of Maoniuping REE deposit, Sichuan, China. J. Mineral. Petrol. 2000, 20, 28-34. (In Chinese with English abstract)

36. Shi, Z.M.; Li, X.Y. Geologic features and ore-forming conditions of alkali complexhosted ore deposits of REE in Himalayan epoch in Panzhihua-Xichang region. Sichuan Geol. Acta 1996, 16, 54-59. (In Chinese with English abstract)

37. Yang, G.M.; Chang, C.; Zuo, D.H.; Liu, X.L. Geology and Mineralization of the Dalucao REE Deposit in Dechang County. Sichuan Province; China University of Geosciences: Wuhan, China, 1998; pp. 1-89. (In Chinese)

38. Liu, Y.; Zhang, R.Q.; Zhang, Z.Y.; Shi, G.h.; Zhang, Q.C.; Zhang, Q.C.; Abuduwayiti, M.; Liu, J.H. Mineral inclusions and SHRIMP U-Pb dating of zircons from the Alamas nephrite and granodiorite: Implications for the genesis of a magnesian skarn deposit. Lithos 2015, 212-215, 128-144. [CrossRef]

39. Liu, Y.; Chen, Z.Y.; Yang, Z.S.; Sun, X.; Zhu, Z.M.; Zhang, Q.C. Mineralogical and geochemical studies of brecciated ores in Dalucao REE deposit, Sichuan Province, southwestern China. Ore Geol. Rev. 2015, 70, 613-636. [CrossRef]

40. Hou, Z.Q.; Tian, S.H.; Xie, Y.L.; Yuan, Z.X.; Yang, Z.S.; Yin, S.P.; Fei, H.C.; Zou, T.R.; Li, X.Y.; Yang, Z.M. Mianning-Dechang Himalayan REE belt associated with carbonatite-alkalic complex in eastern Indo-Asian collision zone, southwest China: Geological characteristics of REE deposits and a possible metallogenic model. Miner. Diposita 2008, 27, 145-176. (In Chinese with English abstract)

41. Niu, S.Y.; Hu, H.B.; Mao, W. Distribution and origin of strata (rocks) in Luxi Shandong. Geosci. Front. 2003, 10, 371-372. (In Chinese with English abstract)

42. Wang, X.M.; Zhong, D.L.; Li, L. Relationship between NW faults of West Shandong and Yi-Shu fault zone in Late Mesozoic and their geotectonic setting operations. Front. Earth Sci. 2010, 17, 166-182. (In Chinese with English abstract)

43. Shi, X.P.; Li, L.; Hu, Q.Y.; Tang, Z. Characteristics of NW-trending Normal Faults and Physical Modeling since Late Mesozoic in West Shandong Uplift, China. Acta Sci. Nat. Univ. Sunyatseni 2010, 2, 24. (In Chinese with English abstract)

44. Li, J.K.; Yuan, Z.X.; Bai, G.; Chen, Y.C.; Wang, D.H.; Ying, L.J.; Zhang, J. Ore-forming fluid evolvement and its controlling to REE (AG) mineralizing in the Weishan deposit, Shandong. J. Miner. Petrol. 2009, 29, 60-68. (In Chinese with English abstract)

45. Zhao, G.C.; Wilde, S.A.; Cawood, P.A.; Sun, M. Archean blocks and their boundaries in the North China Craton: Lithological, geochemical, structural and P-T path constraints and tectonic evolution. Precambrian Res. 2001, 107, 45-73. [CrossRef]

46. Zhang, H.F.; Sun, M.; Zhou, X.H.; Ying, J.F. Geochemical constraints on the origin of Mesozoic alkaline intrusive complexes from the North China Craton and tectonic implications. Lithos 2005, 81, $297-317$. [CrossRef]

47. Yang, J.H.; O’Reilly, S.; Walker, R.J.; Griffin, W.; Wu, F.Y.; Zhang, M.; Pearson, N. Diachronous decratonization of the Sino-Korean craton: Geochemistry of mantle xenoliths from North Korea. Geology 2010, 38, 799-802. [CrossRef]

48. Zhang, X.M.; Zhang, Y.Q.; Ji, W. Fault distribution Patterns of Faults and Mesozoic Sedimentary-MagmaticTectonic Evolution Sequences in Luxi Block, Shandong Province. J. Geom. 2007, 13, 163-172. (In Chinese with English abstract)

49. Kong, Q.Y.; Zhang, T.Z.; Yu, X.F.; Xu, J.X.; Pan, Y.L.; Li, X.S. Deposits in Shandong Province; Shandong Science and Technology Press: Jinan, Shandong, China, 2006; pp. 390-409. (In Chinese)

50. Liang, Y.W.; Lai, Y.; Hu, H.; Zhang, F. Zircon U-Pb Ages and Geochemical Characteristics Study of Syenite from Weishan REE Deposit, Western Shandong. Acta Sci. Nat. Univ. Pekinensis 2017, 53, 652-666. 
51. Yu, X.F.; Tang, H.S.; Han, Z.Z.; Li, C.Y. Geological characteristics and origin of rare earth elements deposits related with alkaline rock in the Chishan Longbaoshan area, Shandong Province. Acta Geol. Sin. 2010, 84, 407-417. (In Chinese with English abstract)

52. Bish, D.L.; Post, J.E. Modern Powder Diffraction; Mineralogical Society of America: Washington, DC, USA, 1989; pp. 101-144.

53. Liu, X.F.; Wang, Q.F.; Feng, Y.W.; Li, Z.M.; Cai, S.H. Genesis of the Guangou karstic bauxite deposit in western Henan, China. Ore Geol. Rev. 2013, 55, 162-175. [CrossRef]

54. Liu, Y.; Hou, Z.Q.; Tian, S.H.; Zhang, Q.C.; Zhu, Z.M.; Liu, J.H. Zircon U-Pb ages of the Mianning-Dechang syenites, Sichuan Province, southwestern China: constraints on the giant REE mineralization belt and its regional geological setting. Ore Geol. Rev. 2015, 64, 554-568. [CrossRef]

55. Hu, M.Y.; Fan, X.T.; Stoll, B.; Kuzmin, D.V.; Liu, Y.; Liu, Y.S.; Wang, G.; Zhan, X.C.; Jochum, K.P. Preliminary characterisation of new reference materials for microanalysis: Chinese geological standard glasses (CGSG)-1, $-2,-4$ and -5. Geostand. Geoanal. Res. 2011, 35, 235-251. [CrossRef]

56. Liu, Y.S.; Hu, Z.C.; Gao, S.; Günther, D.; Xu, J.; Gao, C.; Chen, H.H. In situ analysis of major and trace elements of anhydrous minerals by LA-ICP-MS without applying an internal standard. Chem. Geol. 2008, 257, 34-43. [CrossRef]

57. McDonough, W.F.; Sun, S.S. The composition of the Earth. Chem. Geol. 1995, 120, 223-253. [CrossRef]

58. Haas, J.; Shock, E.L.; Sassani, D. Rare earth elements in hydrothermal systems: Estimates of standard partial molal thermodynamic properties of aqueous complexes of the rare earth elements at high. Geochim. Cosmochim. Acta 1995, 59, 4329-4350. [CrossRef]

59. Yang, Z.M.; Woolley, A. Carbonatites in China: A review. J. Asia. Earth Sci. 2006, 27, 559-575. [CrossRef]

60. Williams-Jones, A.E.; Migdisov, A.A.; Samson, I.M. Hydrothermal mobilization of the rare earth elements-A tale of "bceria" and "byttria". Elements 2012, 355-360. [CrossRef]

61. Hoshino, M.; Sanematsu, K.; Watanabe, Y. Chapter 279-REE Mineralogy and Resources. In Handbook on the Physics and Chemistry of Rare Earths; Jean-Claude, B., Vitalij, K.P., Eds.; Elsevier: Amsterdam, The Netherlands, 2016; pp. 129-291.

62. Pirajno, F. Reviews in Economic Geology. In Rare Earth and Critical Elements in Ore Deposits, Reviews in Economic Geology; Verplanck, P.L., Hitzman, M.W., Eds.; Society of Economic Geologists, Inc.: Littleton, CO, USA, 2016; Volume 18.

63. Ying, J.F.; Zhou, X.H.; Zhang, H.F. Geochemical and isotopic investigation of the Laiwu-Zibo carbonatites from western Shandong Province, China and implications for their petrogenesis and enriched mantle source. Lithos 2004, 75, 413-426. [CrossRef]

64. Liu, S.; Fan, H.R.; Yang, K.F. Fenitization in the giant Bayan Obo REE-Nb-Fe deposit: Implication for REE mineralization. Ore Geol. Rev. 2018, 94, 290-309. [CrossRef]

65. Tian, J.X.; Zhang, R.T.; Fan, Y.C.; Li, X.Z.; Xu, H.Y.; Wang, B.Y. Geological characteristics and relation with rare earth elements of alkalic complex in Chishan of Shandong Province. Geol. Shandong Prov. 2002, 18, 21-25. (In Chinese with English abstract)

66. Hou, Z.Q.; Tian, S.H.; Yuan, Z.X.; Xie, Y.L.; Yin, S.P.; Yi, L.S.; Fei, H.C.; Yang, Z.M. The Himalayan collision zone carbonatites in western Sichuan, SW China: Petrogenesis, mantle source and tectonic implication. Earth Planet. Sci. Lett. 2006, 244, 234-250. [CrossRef]

67. Li, X.C.; Zhou, M.F. The nature and origin of hydrothermal REE mineralization in the Sin Quyen deposit, northwestern Vietnam. Econ. Geol. 2018, 113, 645-673. [CrossRef]

68. Migdisov, A.A.; Williams-Jones, A.E. A spectrophotometric study of Nd (III), Sm (III) and Er (III) complexation in sulfate-bearing solutions at elevated temperatures. Geochim. Cosmochim. Acta 2008, 72, 5291-5303. [CrossRef]

69. Migdisov, A.A.; Williams-Jones, A.E. Hydrothermal transport and deposition of the rare earth elements by fluorine-bearing aqueous liquids. Miner. Deposita 2014, 49, 987-997. [CrossRef]

70. Richards, J.R. Alkalic-type epithermal gold deposit-A review. In Magmas, Fluid, and Ore Deposits; Thompson, J.F.H., Ed.; Mineralogical Association of Canada: Quebec, QC, Canada, 1995; pp. 367-400.

71. Wood, S.A. The aqueous geochemistry of the rare-earth elements and yttrium 2. Theoretical predictions of speciation in hydrothermal solutions to $350^{\circ} \mathrm{C}$ at saturation water vapor pressure. Chem. Geol. 1990, 88, 99-125. [CrossRef] 
72. Trofanenko, J.; Williams-Jones, A.E.; Simandl, G.J.; Migdisov, A.A. The nature and origin of the REE mineralization in the Wicheeda Carbonatite, British Columbia, Canada. Econ. Geol. 2016, 111, 199-223. [CrossRef]

73. Kynický, J.; Smith, M.P.; Song, W.L.; Chakhmouradian, A.R.; Xu, C.; Kopriva, A.; Galiova, M.V.; Brtnicky, M. The role of carbonate-fluoride melt immiscibility in shallow REE deposit evolution. Geosci. Front. 2018, 1-12. [CrossRef]

74. Williams-Jones, A.E.; Samson, I.M.; Olivo, G.R. The genesis of hydrothermal fluorite-REE deposits in the Gallinas Mountains, New Mexico. Econ. Geol. 2000, 95, 327-341. [CrossRef]

75. Song, W.L.; Xu, C.; Smith, M.P.; Kynichy, J.; Huang, K.J.; Wei, C.W.; Zhou, L.; Shu, Q.H. Origin of unusual HREE-Mo-rich carbonatites in the Qinling orogen, China. Sci. Rep. 2016, 6, 37377. [CrossRef] [PubMed]

76. Williams-Jones, A.E.; Vasyukova, O.V. The Economic Geology of Scandium, the Runt of the Rare Earth Element Litter. Econ. Geol. 2018, 113, 973-988. [CrossRef]

(C) 2019 by the authors. Licensee MDPI, Basel, Switzerland. This article is an open access article distributed under the terms and conditions of the Creative Commons Attribution (CC BY) license (http://creativecommons.org/licenses/by/4.0/). 